Portland State University

PDXScholar

1981

\title{
The political and constitutional significance of the Exclusion Crisis of 1678-1681
}

Susan Diane Meyer-Strom

Portland State University

Follow this and additional works at: https://pdxscholar.library.pdx.edu/open_access_etds

Part of the European History Commons, and the Political History Commons Let us know how access to this document benefits you.

\section{Recommended Citation}

Meyer-Strom, Susan Diane, "The political and constitutional significance of the Exclusion Crisis of 1678-1681" (1981). Dissertations and Theses. Paper 3076.

https://doi.org/10.15760/etd.3070

This Thesis is brought to you for free and open access. It has been accepted for inclusion in Dissertations and Theses by an authorized administrator of PDXScholar. Please contact us if we can make this document more accessible: pdxscholar@pdx.edu. 
AN ABSTRACT OF THE THESIS OF Susan Diane Meyer-Strom for the Master of Arts in History presented March $31,1981$.

Title: The Political and Constitutional Significance of the Exclusion Crisis of $1678-1681$.

APPROVED BY MEMBERS OF THE THESIS COMMITTEE:

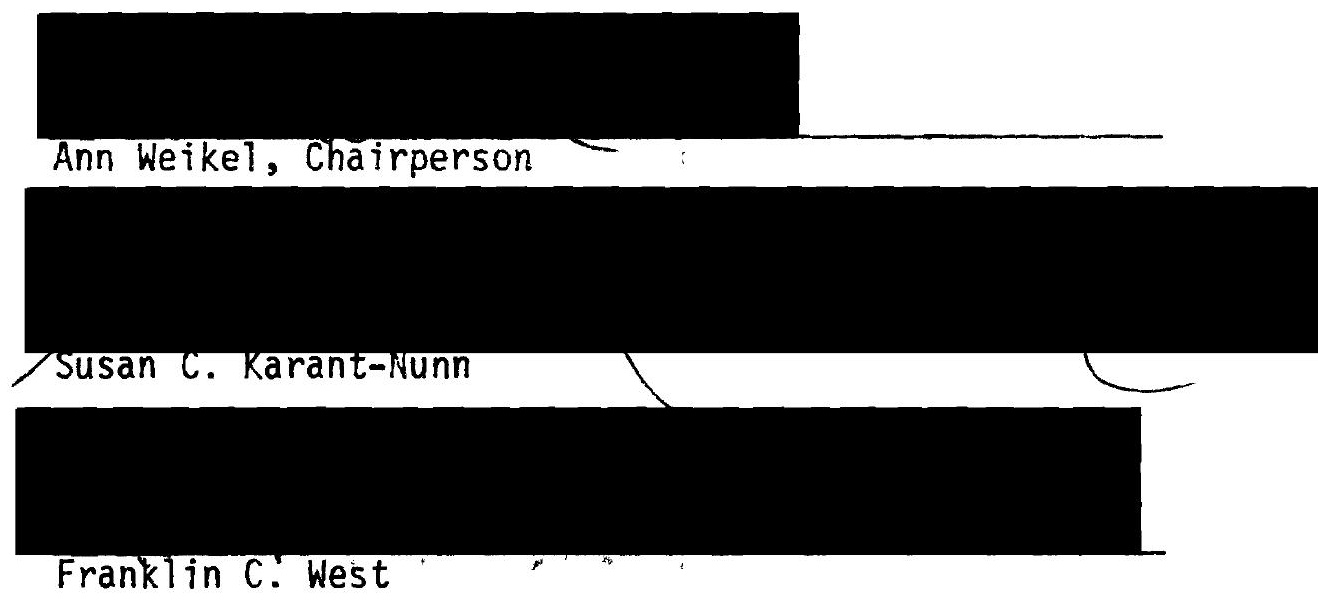

By examining the attacks waged against the royal prerogative during the Exclusion Crisis of $1678-1681$, this thes is asserts that the crisis was primarily constitutional in nature, rather than religious. This Parliamentary attempt to remove the Catholic heir presumptive from the succession endangered the monarchy by creating a Parliamentary title to the throne. Insofar as the exclusionists challenged the king's right to retain ministers at will, to grant pardons, and to determine the calling and dissolution of Parliamentary sessions, the crisis also constituted a direct assault upon the prerogatives of the present king. The implementation of Parliament's proposal to guarantee a Protestant 
succession by arrogating to a Protestant Association many rights of the monarch would have tipped permanently the scales of power in favor of Parliament. The Exclusion Crisis can thus be viewed as an important, albeit abortive, attempt to better define the unresolved roles of the king and Parliament in the governing of England. 
THE POLITICAL AND CONSTITUTIONAL SIGNIFICANCE OF THE EXCLUSION CRISIS OF 1678-1681

by

SUSAN DIANE MEYER-STROM

A thesis submitted in partial fulfillment of the requirements for the degree of

MASTER OF ARTS

in

HISTORY

Portland State University

1981 
TO THE OFFICE OF GRADUATE STUDIES AND RESEARCH:

The members of the Committee approve the thesis of Susan Diane Meyer-Strom presented March 31, 1981.

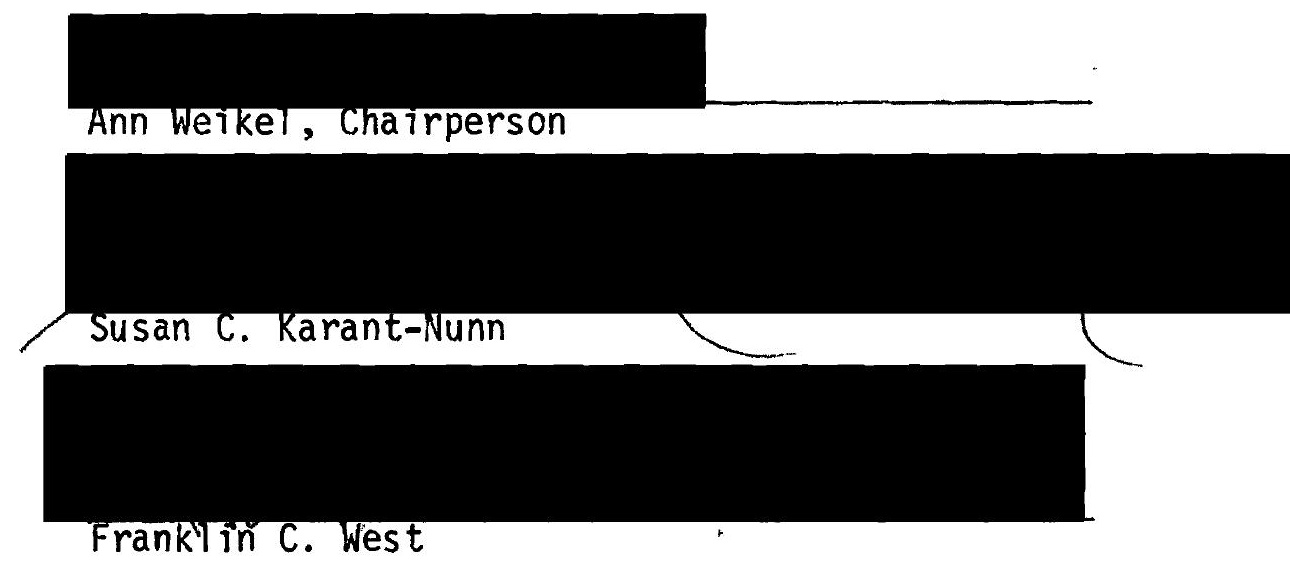

APPROVED:

Frederick M. Nunn, Head, Department of History

Stanley E. Rauch, Dean of Graduate Studies and Research 
TABLE OF CONTENTS

CHAPTER

PAGE

I INTRODUCTION ........................ 1

II THE HISTORICAL BACKGROUND ........... 7

III THE END OF THE CAVALIER PARLIAMENT:

PRELUDE TO EXCLUSION . . . . . . 24

IV THE FIRST EXCLUSION PARLIAMENT . . . . . . . . 42

V THE LINES HARDEN . . . . . . . . . . . . 67

VI THE SECOND AND THIRD EXCLUSION PARLIAMENTS . . • 86

VII CONCLUSION .......................... 105

BIBLIOGRAPHY ........................ 110 


\section{CHAPTER I}

\section{INTRODUCTION}

The Exclusion Crisis is commonly viewed as a Parliamentary effort to remove the heir presumptive from the succession on the grounds of his adherence to the Catholic faith. Many Englishmen, both in and out of Parliament, claimed that the exclusion from the succession of James, Duke of York, was necessary in order to protect the Church of England from certain ruin at the hands of a Catholic monarch. Speeches and pamphlets painted a grim picture of the horrors which must inevitably accompany the accession of a Catholic to the throne. Despite the rabidly anti-Catholic temper of the years 1678-1681, fed by the "discoveries" of the Popish Plot, one can question whether James's Catholicism was the real issue during the crisis. This thesis contends that the Exclusion Crisis involved more than religion; indeed, that political considerations were primary.

Many people certainly feared that the dogmatic and uncompromising James would attempt to re-Catholicize England once he came to the throne. But in addition to the loss of religion, those who recognized a link between Catholicism and absolutism expressed fears for the loss of their liberties as well. The Earl of Shaftesbury, the driving force behind the exclusion movement, wrote that the most important reason for excluding James was that James was the chief agent of arbitrary government in England. Clearly, the powers 
exercised by the king concerned Shaftesbury far more than the loss of religion. Since the leading proponent of exclusion considered the Catholicism of the prospective heir to be less abhorrent than his tendencies towards absolutism, it is possible to see in the crisis political considerations operating on par with religious bigotry. An examination of the issues raised during the course of the crisis reveals a thread which runs through much of Stuart history--the unresolved relationship between the king and Parliament.

The rapturous welcome given Charles II in 1660 had worn thin by the late 1670s, as Englishmen warily assessed their king's behavior and intentions. They saw much to alarm them: the provocative policies of the Cabal, Danby's attempt to manage Parliament and to gain financial independence for the Crown, the king's apparent acquiescence in the face of French aggression on the continent, his French-Catholic mistress, and his doubtful devotion to the Church of England. The fury which accompanied the outbreak of the Popish Plot in 1678 played into the hands of those who were ready for a re-assessment of the roles of king and Parliament in the governing of England.

No clear definition of the king's prerogatives existed during the Restoration. In the days before the civil war, Charles I had consented to several acts limiting the royal prerogative. These acts remained in force when his son ascended the throne in 1660 . Charles II could not re-establish the old prerogative courts, nor could he resort to feudal financial exactions in order to obtain money. The restored king retained his control over foreign policy 
and the armed forces, the right to determine the timing of sessions of Parliament, and the right to decide upon the selection and retention of Crown ministers.

Like his father, Charles II faced a Parliament determined to have a voice in foreign affairs, intent on ridding the realm of unpopular ministers, and leery of the king's religious proclivities. Throughout his reign Charles II skilfully parried with Parliament, one time reprimanding members for encroaching upon his prerogatives, and at another sidestepping a contest by either giving in to their demands or by exercising his right to prorogue Parliament. The relationship between the king and Parliament became increasingly strained as both parties sought to define their roles to their own advantage. Longstanding grievances between the king and Parliament, left unsettled at the Restoration, would continue to plague England until their resolution in 1688. The Exclusion Crisis can be viewed as a chapter in the ongoing process of defining the balance of power between king and Parliament.

This thesis maintains that, in resisting the exclusion of his brother from the succession, Charles II was fighting a larger battle than has been presumed. Charles's defense of James's rights was certainly not based merely upon fraternal affection. From the start, Charles realized that the exclusion movement constituted a major political crisis rather than an interval of anti-Catholicism run amuck. The king perceived the real danger of exclusion to lie, not in the dashing of James's expectations, but in the threat to the royal prerogative implied by exclusion. An exclusion bill would 
undermine the foundations of the monarchy, rendering the king permanently dependent upon Parliament. By acknowledging a Parliamentary title to the throne, the Stuart kings would finally be abandoning the conviction that their authority and prerogatives were endowed by God, rather than derived from the people. Could a king with a Parliamentary title to the throne ever exercise his prerogatives without Parliament's consent and blesssing? In addition to its implied threat to the prerogative, Charles saw in the crisis the first step in a new campaign designed to cut into his own powers. By an examination of the Exclusion Parliaments, I will demonstrate that the Exclusion Crisis involved far more than James's religion. An analysis of the issues raised during the Parliaments reveals that the campaign to exclude James from the succession was as much an effort to redefine the limits of royal authority as it was an attempt to protect the Church of England. The repeated attacks members made upon the royal prerogative bear out the king's assertion that Shaftesbury's goals were primarily political. In the autumn of 1678 both Houses of Parliament passed a Militia Bill which encroached upon the king's right to control the nation's armed forces. This session of Parliament al so witnessed an attack upon the king's right to retain ministers at will. The campaign to impeach the Earl of Danby involved more than a challenge to the royal prerogative of selecting Crown ministers. It signaled the development of a new political principle which threatened the power of the king--the principle that a minister bore responsibility for unpopular, as well as $i l$ legal, acts carried out by royal command. 
The members of the House of Commons renewed this assault on Danby during the first Exclusion Parliament in the spring of 1679 . Addresses for the removal of Danby's associates again encroached upon the prerogative. The struggle over Danby's impeachment produced another challenge to the royal prerogative, when members denied the king's right to pardon his minister for all alleged crimes. The House of Commons proposed an election reform bill which required that no Parliament sit for longer than two years. This bill constituted a direct usurpation of the king's right to determine the dissolution of Parliament. A proposal that the royal guards be replaced by the militia reflected the House of Commons' hostility towards the monarchy.

The second Exclusion Parliament offered increasingly extravagant challenges to the royal prerogative. Members of the House of Commons once again attacked ministers who encouraged the king's opposition to exclusion. A provision of the Exclusion Bill rendered the king incapable of pardoning anyone who supported James's claim to the throne, an act of treason according to the bill. Commons' insistence that an Exclusion Bill be accompanied by the creation of a Protestant Association confirmed Charles's suspicions about the intentions of the exclusionists. The creation of such an Association would rob the king of much of his authority. Several towns, arsenals, and ports would fall under the jurisdiction of the Association. Parliament would supervise the appointment of men to every position of power and influence in the nation. 
The members of the House of Commons continued their assault on the prerogative during the short-lived third Exclusion Parliament in the spring of 1681 . Members of the House received detailed instructions from the Whig leaders, ordering them to accept only exclusion and to pass a bill requiring annual Parliaments.

Charles correctly perceived exclusion as a double-edged sword. The creation of a Parliamentary title to the throne, combined with measures the Whigs considered necessary to guarantee exclusion, would result in the virtual annihilation of monarchial authority. A] though his Whig opponents denied any desire to encroach upon the royal prerogative, the bills they proposed and the questions they raised in Parliament indicate that the implementation of their goals would seriously clip the wings of the monarch. As Bishop Burnet wrote in his History of His Own Time, "the King came to think that he himself was levelled at chiefly, though for decency's sake his brother was only named." 1

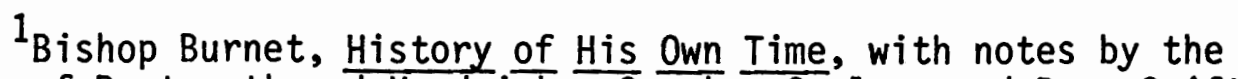
Earls of Dartmouth and Hardwicke, Speaker Onslow, and Dean Swift, 6 vols. (Oxford: University Press, 1833), Vo1. II, p. 259. 


\section{THE HISTORICAL BACKGROUND}

The struggle between Charles II and Parliament over the nature and extent of the royal prerogative did not begin with the Exclusion Crisis. The king's prerogative right to dispense with the law proved several times to be a point of contention between Charles II and Parliament. The first Declaration of Indulgence, issued late in 1662, provided such a contest. In accordance with his promise to allow liberty for tender consciences, Charles declared his intention of dispensing with penal laws against the Puritans. Both Houses of Parliament immediately made clear their hostility to such a plan. The Speaker of the House of Commons informed the king that the House would never cooperate with this executive effort to effect the legal toleration of non-Anglicans. The House of Lords voted down a bill which would allow Charles to use his prerogative powers to dispense with the Act of Uniformity. ${ }^{2}$ Faced with the overwhelming opposition of his Anglican Parliament, Charles did not press the point.

Charles faced similar parliamentary opposition ten years later when he issued a second Declaration of Induigence. Citing his supremacy in ecclesiastical matters, Charles in March of 1672 issued a declaration suspending penal laws against both dissenters and

\section{Maurice Ashiey, Charles II: The Man and the Statesman (New} York: Praeger Publishers, 1971), p. 118. 
recusants. The declaration granted dissenters the right to establish conventicles if they were conducted by ministers licensed by the Crown. Catholics would be allowed to worship in private homes. This declaration was not mereiy the act of a beneficent king, intent upon establishing religious toleration. It was a move calculated to win support for the war with the Dutch, which was declared just three days after the issuing of the declaration. Charles seriously miscalculated the reaction to this declaration of the majority of Englishmen, who saw it as part and parcel of an insidious design to give free rein to Catholicism at home.

A disgruntled Parliament met in February of 1673 . In addition to their anger over the Declaration of Indulgence, members were alarmed by what they perceived as other unbridled executive actions. Charles declared the Third Dutch War without consultation with Parliament, and indeed he waged it partiy with money voted to support an alliance with the Dutch. The king obtained additional money for the war by a royal order postponing the repayment of government debts to the bankers, a scheme known as the Stop of the Exchequer, and which Commons condemned as unparliamentary taxation. The attack which members waged on the king's suspending power reflected Parliament's displeasure with the Declaration of Indulgence. In addressing Charles to withdraw the declaration the House of Commons voted "that penal statutes in matters 
ecclesiastical cannot be suspended but by Act of Parliament." 3

Charles reproached Commons for an unwarranted questioning of his ecclesiastical power, to which Commons responded:

- . we humbly conceive your Majesty hath been very much misinformed; since no such power was ever claimed or exercised by any of your predecessors: and if it should be admitted, might tend to the interrupting of the free course of the laws, and altering of the legislative power, which hath always been acknowledged to reside in your Majesty and your two Houses of Parliament."

The House of Commons did not remain idle. While they waited for the king's reply to their address, members moved to express their distaste for Catholicism in tangible form. William Sacheverell, who would later be a vociferous advocate of exclusion, proposed that all recusants be removed from military and civil office. ${ }^{5}$ A bill requiring that any person who refused to take the oaths of allegiance and supremacy, and to receive the sacrament according to the rites of the Church of England, would be excluded from civil and military office embodied this proposal. Charles reluctantly abandoned his Declaration of Indulgence and consented to the Test Bill in order to obtain supply for the continuation of the war. In the case of both Declarations of Induigence, the king found it expedient to back down in the face of overwhelming Parliamentary opposition, but he did so without openly

${ }^{3}$ Thomas Pitt Taswe11-Langmead, English Constitutional History (Houghton Mifflin, 1947), p. 447.

${ }^{4}$ Ibid.

${ }^{5}$ Sir George Sitwel1, The First Whig: An Account of the Parliamentary Career of William Sacheverel1, The Origin of the Two Great Political Parties, and the Events Which Led Up to the Revolution of 1688, (Scarborough: Author's Private Press, 1894 ), p. 10. 
renouncing his right to suspend the law. Parliament won a victory without the king acknowledging defeat; the question of the extent of the royal prerogative to suspend the law was thus left unanswered.

The king and Parliament also exchanged sharp words over the extent of the executive power to decide questions of war and peace. Charles resented receiving unsolicited Parliamentary advice concerning the conduct of foreign policy. The Parliament which met early in 1673 took time away from their attack on the Declaration of Induigence to declare for peace with the Dutch and hostility to France. 6

The House of Commons sounded a similar note in May of 1677. With only two dissenting votes, members voted an address to the king urging an alliance with the Dutch against France. ${ }^{7}$ The carefully worded address implied that once Charles concluded such an alliance, Commons would vote supplies sufficient to enable the king to make war. Aggrieved at this encroachment upon the royal prerogative to make war and peace, Charles replied:

You have intrenched upon so undoubted a right of the crown that I am confident it will appear in no age (when the sword was not drawn) that the prerogative of making peace and war hath been so dangerously invaded.

If he consented to the address, allowing Parliament to dictate foreign policy, ". . no prince in Europe would any longer believe that the sovereignity of England rests in the Crown." 8 The king prorogued

Wilbur C. Abbott, "The Origin of English Political Parties," American Historical Review, XXIV (July 1919), p. 599.

${ }^{7}$ Sitwel1, First Whig, p. 17.

${ }^{8}$ J.R. Tanner, English Constitutional Conflicts of the Seventeeth Century, 1603-1689 (Cambridge: University Press, 1962), p. 237. 
Parliament until January of 1678, and in the intervening months Charles decided to conclude an alliance with the Dutch.

The House of Commons greeted news of the Dutch alliance with suspicion. Sacheverell warned members that they were being deceived by the king's apparent acquiescence to their address and openly speculated that Charles had negotiated a secret treaty with Louis XIV. 9 Once again, Charles angrily reproached Commons for encroaching upon a fundamental royal prerogative. Commons' lack of faith in Charles II proved to be justified. On March 20 the king assented to a tax bill which stipulated that all money raised be expended on hostilities against France. Just five days later Charles instructed his ambassador to France to ask Louis XIV for a subsidy in exchange for Charles's guarantee that England would not go to war with France. 10

The presence in the king's counsels of unpopular ministers, a familiar condition throughout the seventeenth century, provided another source of conflict between the king and Parliament. The king's prerogative right to appoint, retain, or remove ministers at his own discretion faced frequent Parliamentary challenges during the reign of charles II. The damage done to the prerogative by the impeachment of the Earl of $\mathrm{Cl}$ arendon in 1667 was twofold. Clarendon's condemnation in Parliament and his subsequent removal from office encouraged politicians to obtain office by attacking rival ministers

${ }^{9}$ Sitwe 17, First Whig, p. 18.

10 K.H.D. Haley, The First Earl of Shaftesbury (0xford: Clarendon Press, 1968), p. 487. 
in Parliament. The Parliamentary attack on the king's chief minister, undertaken albeit with the king's blessing, inspired members to more frequent criticism of the conduct of government. ${ }^{11}$ Charles unwisely encouraged the conviction that the king should dismiss unpopular ministers. He exhorted Parliament to express its appreciation for the removal of $\mathrm{Clarendon}$ by presenting him with an address of thanks.

Members of Parliament took this lesson to heart, for the 1670 s saw increased numbers of attacks on the king's ministers. Parliament watched the activities of the king and his ministers with mounting alarm, and they soon came to feel that their most cherished liberties and religion were under siege. The attempted toleration of recusants and dissenters threatened the inviolable position of the Church of England. Charles attempted to circumvent the accepted means of raising money for war by resorting to the Stop of the Exchequer. This move endangered the House of Commons' chief means of obtaining a voice in government, their control of the purse. Members were incensed by the Duke of Lauderdale's assertion that the king's declarations had the force of 1aw. Many men suspected that the Treaty of Dover contained secret clauses providing for the restoration of Catholicism and the establishment of absolutism in England by means of French arms. Louis XIV's successes on the continent cast a threatening shadow over English religion and liberties. These developments led members of Parliament to turn against those

${ }^{11} \mathrm{Cl}$ ayton Roberts, The Growth of Respons ible Government in Stuart England (Cambridge: University Press, 1966), p. 171. 
ministers whom they held responsible for dangerous executive policies, and to challenge the king's prerogative to select and retain ministers at his own discretion.

The ire of Parliament destroyed the working relationship of the Cabal, an acronym for the first letters of the names of the leading ministers: Clifford, Arlington, Buckingham, Ashley and Lauderdale. The Cabal ministers escaped impeachment early in 1673 only when Charles withdrew his offending Declaration of Indulgence. The Test Act forced the Catholic Clifford to resign from office. ${ }^{12}$ Ashley (the future Earl of Shaftesbury) defected to the opposition, and in November of 1673 was asked to deliver up his seals of office to the king. ${ }^{13}$ Arlington survived an attempted impeachment, but lost much of his political influence and resigned from office in June of 1674. 14 Despite Buckingham's obsequious attempts to exculpate himself from all blame for policies of the Cabal government, Commons in 1673 and 1674 voted addresses to Charles asking for his removal. Charles dismissed Buckingham, but not to propitiate Parliament. During Buckingham's futile attempt to exonerate himself before Commons, he had violated his oath of secrecy as a Privy Councillor. 15

12 Maurice Lee, Jr., The Cabal (Urbana: University of 111 inois Press, 1965), p. 225.

${ }^{13}$ Haley, First Earl, p. 342.

${ }^{14}$ Keith Feiling, A History of the Tory Party, 1640-1714 (0xford: Clarendon Press, 1924), p. $\frac{154}{154}$

15 Roberts, Growth, p. 191. 
Parliament bore a deep-seated enmity for the Duke of Lauderdate, the king's governor in Scotland. They feared that he advised Charles to establish arbitrary government in England, and that he offered to provide Scottish troops to support such an effort. Commons voted five addresses to the king asking for the removal of Lauderdale. These addresses constituted a direct attack on the king's prerogative right to choose his own ministers. Lauderdale survived all of the addresses voted against him.

The king's prerogative right to choose his ministers was a source of much contention between king and Parliament in the decade preceding the Exclusion Crisis. With the coming of the Exclusion Crisis the nature of Parliamentary attacks on royal ministers changed, and a new principle of ministerial responsibility developed. 16

The king's prerogative right to summon, prorogue and dissolve Parliament at will also came under critical scrutiny during the 1670s. A modified Trienniar Act, passed in 1664, contained no mechanism for forcing the king to call Parliament after the appointed intervar and so was ineffective. Opponents of the Earl of Danby, who managed Parliament for the king in the mid-1670s, sought to force the king to dissolve Parliament, allowing for the creation of an ungovernable Parliament. In their campaign to effect a dissolution, they repeatedly challenged the king's right to control the timing of sessions of Parliament.

${ }^{16}$ Ibid., pp. $223-224$. 
Acting with Shaftesbury's blessing, Sacheverell in April of 1675 proposed to the House of Commons that sessions of Parliament should not be terminated until all business was completed. He defended this assertion by referring to precedents from the reigns of Edward III, Richard II, and Henry IV. This proposal constituted a direct attack on the king's prerogative to adjourn Parliament at wil1. Despite Sacheverell's best efforts, his proposal met with little enthusiasm from the rank and file members of the House.

The two Houses of Parliament became embroiled in a dispute over their privileges, and in the ensuing deadlock gave little attention to other Parliamentary business. Charles recognized that it was in the best interests of his opponents to instigate the quarrel, and he considered it to be another ploy aimed at forcing a dissolution. He called upon the two Houses to mend their disagreement, and warned them, "But I must let you know, that whilst you are in debate about your privileges, I will not suffer my own to be invaded . . ."17 The two Houses refused to heed the king's call for a reconciliation and on June 9 he prorogued Parliament.

When Parliament reassembled in October, the initiative in the campaign to win a dissolution passed to the House of Lords. On November 20, Lord Mohun moved that an address be presented to Charles, requesting that Parliament be dissolved since the quarrel over their privileges prevented the two Houses from working together. The

${ }^{17}$ Sir Arthur Bryant, ed., The Letters, Speeches and Declarations of Charles II (London: Casse17, 1968), p. 282. 
majority of the temporal lords supported the motion, but the bishops, as a body, voted against it. The motion failed, 50 to $47 .{ }^{18}$ Two days later Charles prorogued Parliament, and left it in abeyance for fifteen months.

When Parliament next met in February of 1677, Shaftesbury used the long prorogation as the basis for his bid for a dissolution. He argued that a prorogation of more than twelve months was illegal and based his contention upon two acts of Edward III, which called for annual Parliaments. These two acts had been ignored in framing the Triennial Acts of 1641 and 1664, and so had not been stricken from the books. ${ }^{19}$ Shaftesbury, Buckingham, Salisbury, and Wharton spoke in favor of a motion for dissolution, but failed to win over most of their comrades in the House. By a vote of 53 to 30 , the four lords were ordered to withdraw from the House. When they refused to apologize for their proposal, the Lords dispatched them to the Tower. ${ }^{21}$ Shaftesbury remained there for a full year before pressing developments obliged the Earl to grit his teeth and apologize, to win his freedom.

In the course of their campaign to win a dissolution of Parliament, Shaftesbury's party published a pamphlet in 1675 entitled "Some Considerations Upon the Question Whether the Parliament is

${ }^{18}$ A.S. Turberville, "The House of Lords Under Charles II, "English Historical Review, XLIV (July 1929), p. 413.

${ }^{19}$ Ibid., p. 414.

${ }^{20}$ Haley, First Earl, p. 418.

21 Ibid., p. 414. 
Dissolved." This pamphlet not only challenged the king's prerogative to decide upon the dissolution of Parliament; it also asserted that Parliament possessed the authority to alter the succession to the Crown. The pamphlet argued that acts of Parliament could restrict the prerogative as well as "bind, limit, restrain and govern the descent and inheritance of the Crown itself, and all rights and titles thereto." 22 The author of the pamphlet is unknown. Shaftesbury denied responsibility for its claim that Parliament possessed the power to alter the succession, but Buckingham insisted that Shaftesbury wrote the offending clause.

The publication of the pamphlet was not the first hint that some members of Parliament were considering encroaching on the most sacrosanct of royal institutions--the principle of hereditary succession to the throne of England. In the summer of 1673, six years before the first Exclusion Parliament, Charles confided to the French ambassador his fears that Parliament might introduce bills to send James into exile and to exclude Catholic princes from the succession. Even at this early date, Charles expressed doubts over whether he could trust Shaftesbury (then Lord Chancellor) to defend James's right to succeed his brother.

For many years, rumors that the heir presumptive to the throne had secretly converted to Catholicism circulated throughout England. James's refusal to participate in the Anglican sacrament at Easter

22 Ibid., p. 331. 
1673 transformed whispered speculation into a universal conviction that James had fallen under the sway of Catholicism.

The prospect of a Catholic monarch filled the hearts of Englishmen with dread. Few words were so widely despised in 17 th century England as that of "Papist." Catholics were viewed as desperate plotters, willing to subvert any law of man or morality in order to bring England back to the Catholic fold. One need look no farther for evidence of Catholic perfidy than to the attempted assassinations of Queen Elizabeth, the Gunpowder Plot of 1605, the Irish massacre of 1641, and the Great Fire of 1666. A Catholic monarch would rely for advice on the Jesuits to reconvert England. Many believed these fanatical soldiers of the pope would stain the country with Protestant blood in their quest for orthodoxy. The succession of a Catholic to the throne would endanger Englishmen's religion, liberties, property and lives. The outbreak of the Popish Plot in 1678 allowed Shaftesbury and his associates to direct this deep and pervasive hatred of Catholicism to political ends.

"Fear of the Duke of York makes them everyday fetter the Crown."23 Edward, third Viscount Conway described the activities of Parliament in early 1674 with these words. Shaftesbury and his fellows sought to exaggerate the dangers posed by a Catholic heir in order to build up a case for exclusion. During a debate on religion, Shaftesbury warned that there were 16,000 armed Catholics in London

$$
{ }^{23} \text { Ibid., p. } 359 .
$$


and he asked the lords to devise a method of protecting the Protestant population from massacre. With only James and two others dissenting, the Lords voted an address asking the king to remove all Catholics from London.

A committee of the House of Lords prepared a bill designed to protect the country from the possibility of a Catholic monarch. The bill required that all of James's children be educated as Protestants, stipulated that in the future neither the king nor any prince could marry a Catholic without the consent of Parliament, and removed all English Catholic priests from Queen Catherine's presence.

The committee raised the possibiltiy of exclusion from the succession during the preparation of the bill. The committee suggested that if any prince were to marry a Cathol ic without Parliament's consent, the penalty would be exclusion. The Archbishop of York called the proposal diabolical. The disapprobation of the episcopate caused the proposal to be dropped.

While the House of Lords debated the feasibility of exclusion, the Commons determined to fetter any king's ability to establish an absolute government. The first Habeas Corpus bill received three readings in the first two months of 1674 . The voting of an address asking the king to dismiss all troops raised since January of 1663 reflected the fear that the king might use a standing army to establish an arbitrary government. Another bill proposed that 
judges hold office during good behavior, and no longer merely at the royal pleasure. 24

None of the bills proposed in Lords or Commons became law, however, for Charles suddenly prorogued Parliament on February 24. The French ambassador sent this report of its adjournment back to his master:

Parliament was prorogued, as one expected, but what surprised everyone was that it was done so suddenly, without warning Parliament of it, or consulting the Council. The King prorogued Parliament because its deliberations tended to lessen his power. .25 and it refused to do anything towards voting supply.

Despite the Earl of Danby's efforts to assuage Anglican criticism of the government's religious proclivities, Parliament remained suspicious of the king's devotion to the established church and openiy hostile to James.

Danby attempted to detract attention from James's Catholicism by introducing a bill in June of 1677 limiting the powers of a Catholic king. The bill required all future monarchs to disavow any belief in transubstantiation. Any king who refused to do so would surrender his right to appoint bishops and would relinquish the supervision of his children's education to a panel of bishops. ${ }^{26}$ Most members of Parliament felt that these limitations were inadequate to protect English religion and liberties from violation at the
${ }^{24}$ Ibid., pp. 354-360.
${ }^{25}$ Roberts, Growth, pp. 195-196.
${ }^{26}$ Feiling, History Tory, p. 166. 
hands of a Catholic monarch. This criticism of the policy of limitations would be heard again during the Exclusion Crisis, when the King offered limitations as an alternative to exclusion.

Fed by James's conversion, the king's Catholic mistress, Louis XIV's successes on the continent and fears about secret clauses in the Treaty of Dover, anti-Catholic hysteria grew apace in the 1670s. 1678 saw the publication of Andrew Marvell's pamphlet "Account of the Growth of Popery and Arbitrary Government in England." In addition to decrying the spread of Catholicism, he commented on the still unresolved question of the nature and extent of the royal prerogative. Marvell clearly favored a very limited definition of the prerogative when he declared, "the King's very Prerogative is no more that that what the Law has determined." 27

Shaftesbury realized that the burgeoning anti-Catholic hysteria could work to his political advantage. His best interests could be served by building distrust of the heir's Catholicism to a fever pitch. William Russell, his close ally in the House of Commons, assisted in this endeavor. While foreign affairs preoccupied most members of the House, Russell worked to direct their attention to the dangers of Catholicism. On March 16, 1678 Russell proposed the setting aside of a day for a debate on the growth and progress of Popery in England. ${ }^{28}$ Realizing that an attack on James would ensue,

27 Antonia Fraser, Royal Charles: Charles II and the Restoration (New York: Alfred A. Knopf, 1979), p. 345. ${ }^{28}$ Haley, First Earl, p. 445. 
Danby managed to schedule the debate so that it fell on the day Parliament was to be adjourned.

Shaftesbury took command of the assault on James's position that the opposition carried out in the House of Lords. He warned his fellow lords that priests and Jesuits did not constitute the greatest danger to England; this distinction he reserved for James. Without mentioning the Duke by name, Shaftesbury spoke of "those who live in this city and apply themselves to an arbitrary government and to introduce the Catholic religion entirely." 29 With a significant gesture, he indicated that James was the object of this description.

Shaftesbury wanted to prevent the establishment of an arbitrary government in England. As he assessed the developments of the 1670 s, Shaftesbury saw increasing evidence that the policies of the Crown boded $i 11$ for English liberties. During the Cabal ministry the executive had attempted to rule by reliance upon the royal prerogative: toleration by royal edict, finance by royal order, frequent prorogations of Parliament, an unpopular foreign policy. Danby sought to put the Crown's financial situation on such sure footing that the king need not depend upon Parliamentary grants of money. A Parliament without financial leverage would be well on its way towards extinction, as evidenced by the fate of the Estates General in France.

${ }^{29}$ Ibid., p. 448. 
Each time Charles II and Parliament clashed over the scope of the royal prerogative, its extent was left undefined. Charles abandoned his Declarations of Indulgence, but he refused to foreswear his right to suspend the law in ecclesiastical matters. He would not abandon his control over foreign policy, his right to control the timing of Parliament, or his power to retain or dismiss ministers of the Crown. The nature and scope of the royal prerogative were still a source of contention between king and Parliament in the summer of 1678. The eruption in August of the Popish Plot confirmed everyone's worst suspicions about the dangers of Catholicism. The Plot offered a new opportunity for Shaftesbury and his associates to avert the creation of an absolute government by defining the rights and roles of both king and Parliament to Parliament's advantage. 


\section{CHAPTER III}

THE END OF THE CAVALIER PARLIAMENT: PRELUDE TO EXCLUSION

It was la familiar tale: a Jesuit plot to murder the king, to place a compliant James on the throne, and then to force England back into the Catholic fold. Yet this hackneyed story of Catholic villainy electrified the nation in the autumn of 1678 , when a string of coincidences and mishaps lent credence to the announcement of the discovery of a new Popish Plot.

The outbreak of the Popish Plot ushered in a new Parliamentary campaign to limit the prerogative. There is no evidence that Shaftesbury had a hand in the creation of the Plot, despite the fact that a new outbreak of anti-Catholic hysteria would perfectly suit Shaftesbury's purposes. The discoveries were made public in the politically inactive month of August, hardly a propitious time for uniting religious zeal with political industry. 30 shaftesbury was not the father of the Plot, but he quickly recognized the advantages to be gained in bringing attention to the dangers of Catholicism and a Catholic heir. If the furor over the discovery of Catholic perfidy could be skilfully orchestrated and directed, Shaftesbury believed he could force the king to accept the exclusion of his brother from

${ }^{30}$ J.R. Jones, Country and Court, England, 1658-1714 (Cambridge: Harvard University Press, 1978), p. 199. 
the succession. This one act would remove the man Shaftesbury regarded as the chief agent of arbitrary government in England. By changing the underlying assumptions about the basis of monarchial claims to power, it would also be a major step in the settling of unresolved constitutional questions. It would be far easier to clip the wings of a monarch with a Parliamentary title to the throne, than to restrict the prerogatives of a king who still claimed accountability only to God. During the course of the Exclusion Crisis, the king's Whig opponents also continued their campaign to limit the prerogatives of the present king. Members challenged the king's authority over the armed forces, and they encroached upon his right to retain ministers at his own discretion.

While strolling through a park in mid-August, Charles was approached by a gentleman of the court who warned the king of a new Jesuit scheme against his life. Charles discounted the story, but Danby persuaded him to submit it to a cursory investigation. On the 28 th and 29th of September, Titus 0ates, the father of the Plot, testified before the Privy Council. A most convincing liar, 0ates regaled the councillors with a painstakingly detailed account of the Jesuit plot to murder the king. The wealth of information he provided combined with his personal bravura persuaded most councillors that the matter warranted further investigation. Accordingly, the Council ordered the arrest of all suspects named by 0ates. After his first meeting with Oates, Charles knew that the man was a liar. Charles attended the Council's interrogation of Oates, where he caught Oates in several lies. He asked Oates to describe 
Don John of Spain, supposedly a key figure in the Plot. Oates described Don John as a tall, dark haired man, whereas he actually was a short redhead. Oates also gave an incorrect description of the site of the Jesuit house in Paris. Had he dared, Charles could have exposed 0ates for the prevaricator that he was. Oates claimed that the details of the assassination plot had been worked out during a Jesuit consult held at the White Horse Tavern on April 24. Supposedly hired as a go-between for the conspirators, Oates claimed to have played along with them until he had accumulated sufficiently incriminating evidence against them. Charles knew that this was not so. A Jesuit consult had been held in London on April 24, but 0ates had had no part in it. With Charles's knowledge, the Jesuits had met in James's quarters at St. James's Palace, hardly information that Charles could impart to his Council. 31

Charles believed that Oates was a tool of Shaftesbury's, carefully coached to incriminated Catholics in general and James in particular. The king confided this belief to Bishop Burnet, who wrote this report of their discussion:

We agreed in one thing, that the greatest part of the evidence was a contrivance. But he suspected, some had set on 0ates, and instructed him: and he named the earl of Shaftsbury. I was of another mind. I thought the many gross things in his narrative shewed, there was gh $^{2}$ abler head than Oates, or Tonge, in the framing of it. Haley, First Earl, p. 454.

${ }^{32}$ Burnet, History, p. 171. 
Al though Oates lied about the Plot, one of the men he named as a conspirator did have an incriminating past. Edward Coleman, a former secretary to the Duke of York, had devoted himself to the cause of re-Catholicizing. England. He had carried on a very indiscreet correspondence with two of Louis XIV's confessors, Fathers Ferrier and LeChaise. When warned that Oates had named him as a principal conspirator, Coleman destroyed much of this correspondence, but unaccountably kept letters from 1674, 1675, and 1676. In selecting Coleman as a conspirator, Oates had accidentaliy named a man who would give plausibility to the stories of a Catholic plot. The discovery of the contents of Coleman's letters damned him and confirmed everyone's worst suspicions about James's intentions.

In one of his letters Coleman had written:

We have here a mighty work upon our hands, no less than the conversion of three kingdoms. . . There never were such hopes of success since the days of Queen Mary, as now in our days, when God has given us a prince, who is become (I may say by miracle) zealous of bejing the author and instrument of so glorious a work. . . .

James denied that he had given Coleman any reason to hope for his cooperation in the re-Catholicizing of England, but no one believed him. The revelations of Coleman's letters ultimately provided the groundwork for the case for exclusion. A committee of the Council read Coleman's letters on October 4 . The Council

33Lord John Russe11, The Life of William, Lord Russell, 2 vols. (London: Longman, Hurst, Rees, Orme and Brown, 1820), Vol. 1, p. 131. 
turned the matter over for investigation to Parliament, which was scheduled to meet later in the month.

The mysterious death of Sir Edmund Berry Godfrey shortly before Parliament met further enhanced the fury caused by Coleman's letters. Godfrey, a well-known magistrate, had received Oates's deposition concerning the Plot. In early October he disappeared, and on the 17 th his body was discovered in a ditch. Londoners assured themselves that he had been murdered by the Jesuits in an attempt to halt the discovery of their plot. (Hardly likely, since a copy of Oates's deposition had been filed with the Privy Council as well as with Godfrey.) $)^{34}$ Whether the result of murder or suicide, Godfrey's death appeared to most Englishmen as the final confirmation of the existence of the Popish Plot.

Parliament opened on October 21 in an atmosphere of crisis, and members took upon themselves the investigation of the Plot. The House of Commons immediately appointed two committees, one to consider ways of preserving the king's safety and another to investigate Godfrey's death. Determined to exploit the Plot for political advantage, Shaftesbury and his associates did all in their power to elevate public hysteria. Parliament sent Sir Christopher Wren to search for explosives in the vaults under Parliament and Whitehall. The members decreed a general day of fasting in order "to implore the mercy and Protection of Al Imighty God to his Majesties Royal

${ }^{34}$ Ashley, Charles II, p. 232. 
Person, and in him to all His Loyal Subjects. "35 Members publically chided a fireworks manufacturer for keeping dangerous explosives in his house.

Both houses of Parliament exploited the public furor over the Plot in order to justify their usurpation of executive action. 36 The Lord Mayor was instructed to increase security precautions in the city. Parliament offered a reward of 120 for the apprehension of any priest or Jesuit. Parliament issued orders forbidding any Englishmen to attend the chapels of Catholic ambassadors, who were themselves forbidden to keep more than four priests in attendance. The House of Commons sent the Privy Council a list of suspects whose names the House wanted made public in a proclamation. On the 24 th of October, the House of Commons ordered the Lord Chief Justice to issue warrants for the arrest of the five Catholic peers named by Oatẹ as leading conspirators.

On October 26, the House of Commons asked the king to expel all recusants from royal palaces. Two days later the House took steps to expel Catholics from Parliament. Commons sent the House of Lords a bill requiring all members of Parliament to swear an oath against transubstantiation and the worship of the Virgin. 37

${ }^{35}$ Francis S. Reynolds, The Attempted Whig Revolution of 16781681 (Rowman and Littlefield, 1937; reprint ed. Totowa, New Jersey: Boydell Press, 1974), p. 19.

${ }^{36}$ Jones, Country and Court, p. 202.

${ }^{37}$ Turberville, "House of Lords," p. 415. 
The initiative in the Parliamentary plan to nullify the dangers of Catholicism did not all belong to the House of Commons. Shaftesbury suggested on November 2 that James be removed from the king's Council and presence. Charles perceived that such a proposal could constitute the first step down the path towards the exclusion of James from the succession. He ordered James to keep a low profile and instructed Danby to prevent a similar motion from being raised in Commons. Danby's ability to manage Commons had long been on the wane. In spite of his best efforts, on November 4 Commons brought forward a motion for the removal of James from the king's presence and Council. In the course of the debate over this motion, the House of Commons first raised the possibility of exclusion, when Sacheverell asked the assembiy:

I would have the Gentlemen of the Long Robe tell me . . . whether the King and Parliament may not dispose of the Succession of the Crown? 38 and wether it be not Praemunire to say the contrary?

Such a question alarmed the king, who realized that if he were forced to abandon James he would be opening the way for restrictions on his own prerogative. In an effort to forestall any discussion of exclusion, Charles appeared hefore both Houses of Parliament on November 9. The king assured members of his devotion to the safety of the Protestant church, and promised his ready consent to any reasonable bills designed to ensure their safety. The king set his

${ }^{38}$ Anchitell Grey, Esq., Debates in the House of Commons, from the Year 1667 to the year 1694,10 vols. (The Strand: T. Becket and P.A. De Hondt, 1769 , , Vol. VI, p. 148. 
face against exclusion when he added the important qualification:

-. . so as they tend not to impeach the right of succession, nor the Descent of the Crown in the true Line; and so as they restrain not his Power, nor the just Rights of any Protestant successor.

Sacheverell ridiculed the King's speech, calling it "a rattle to keep us quiet." He added, "If we have no Security that the Successor shall be a Protestant, you sit down, and can do nothing effectual 1y." 39

Sir Edward Seymour, Speaker of the House of Commons, on November 22 expounded on the king's proposal that the powers of a Catholic successor be limited. Warning members against exclusion with the words "It is not in your interest to make the heir of the Crown desperate," he recommended specific limitations on the powers of any Catholic king.

I would not scruple to take from him dependencies in Church or State, and power to dispose of the public revenue or the militia. I would not scruple to make a law, that upon the demise of the King the Parliament then sitting or, if there be none, that the last Parliagent, shall meet again and continue for a time certain.

The fate of the House of Commons' bill calling for the exclusion of Catholics from membership in Parliament provided a valuable lesson about the worth of restrictive legislation in settling the succession problem. ${ }^{41}$ An emasculated Test Bill passed in the House

$$
\begin{aligned}
& { }^{39} \text { Ibid., p. } 172 . \\
& 40 \text { Ibid., p. } 265 .
\end{aligned}
$$

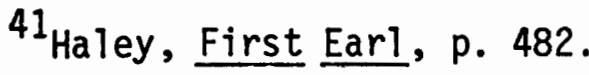


of Lords on November 20. After three weeks of haggling, the royalist majority in Lords managed to insert an amendment onto the bill which vitiated much of the bill's original intent. The amendment exempted James from being disqualified for membership in Parliament on the grounds of his Catholicism. Shaftesbury's associates in the House of Commons were not yet strong enough to command a telling opposition to the amended bill. Despite their best efforts, it squeaked by in the Commons by two votes. In order to gain control of the House of Commons, Shaftesbury's confederates needed to link fear of Catholicism with the dangers of arbitrary government. 42

The House of Commons soon found reason to question the sincerity of the king's promise to do everything possible to protect the Protestant religion. Few images alarmed Englishmen more than that of armed Catholics. According to the Test Act of 1673, all Catholics were to be denied commissions in the army. The House of Commons discovered that Secretary of State Williamson had dispensed Catholic officers from the oath required by the Test Act, as well as countersigning orders granting Catholics army commissions. Williamson had done so under orders from the king. Incensed by this violation of the Test Act, Commons clapped Williamson into the Tower. On the following day, Charles released his secretary. This act convinced many members of Parliament that his promise to defend the faith was valueless. Williamson was so intimidated by his day in custody that

${ }^{42}$ J.R. Jones, The First Whigs: The Politics of the Exclusion Crisis, 1678-1683 (New York, Toronto, and London: Oxford Univers ity Press, 1961), p. 27. 
he thenceforth refused to expedite any illegal orders given him by the king. His timidity cost him his job, for Charles dismissed him in February of 1679. Williamson's dismissal for his refusal to carry out illegal orders reflected a new development in the relationship between the king, his ministers, and Parliament. ${ }^{43}$ During the course of the Exclusion Crisis, it became increasingly difficult for the king to exact obedience from his ministers, who discovered that the king could not always protect them from the ire of Parliament. The years of the Exclusion Crisis witnessed an acceleration in Parliament's campaign to restrict the king's prerogative right to determine the selection and retention of his ministers.

The autumn of 1678 saw another Parliamentary attempt to encroach upon the prerogatives of the monarch. Parliament was determined to protect the nation from a Catholic uprising, and decided that the militia must be kept in a state of readiness. Both Houses of Parliament gave speedy passage to a bill which invested the deputy lieutenants with the authority to keep the militia in being for 42 days. On the same day that Charles gave reluctant consent to the new Test Bill, he vetoed the Militia Bill. The king expressed his determination not to acquiesce to any Parliamentary usurpation of royal power. He told the members:

- . for the right of the Militia being in the Crown, he would not consent to any Act that might put it out, though but for half an hour.

$$
\begin{aligned}
& { }^{43} \text { Roberts, Growth, pp. } 224-225 . \\
& { }^{44} \text { Grey, Debates, V01. VI, p. } 301 .
\end{aligned}
$$


Burnet concurred with the king's fear that the Militia Bill constituted a thinly veiled attack on the prerogative.

I found some of them hoped, when that bill passed into a law, they would be more masters; and that the militia would not separate $t i 11$ all the demands of the two houses should be granted.

As the session progressed, Oates's claims grew more extravagant. On November 24 he accused Queen Catherine and her physician Wakeman of complicity in the plot to assassinate the king. Charles knew this to be patently absurd, and he did all in his power to protect his wife from Oates's incriminations. He could not help other innocents accused by Oates of collusion in the Popish Plot. Trials for participation in the Plot began in November and netted, among others, Jesuits, a Catholic banker, and, of course, Coleman.

The king's rejection of the Militia Bill provoked a furious attack on Danby, whom many held accountable for the king's decision to veto the bill. By a vote of 138 to 114 , the House of Commons on December 2 carried an address to the king, requesting that he remove Danby from office and court and that he stop taking private counsels. ${ }^{46}$ Commons wanted the Crown's ministers to be held accountable for the advice that they offered the king. They sought to establish more clearly ministers' responsibility by requiring that all counsel be given publicily. This, again, was part of the ongoing process of making ministers accountable to Parliament for

${ }^{45}$ Burnet, History, p. 171.

${ }^{46}$ Andrew Browning, ed., Memoirs of Sir John Reresby (Glascow: Jackson, Son, and Co., 1936), p. 161. 
their actions.

Few things would delight Shaftesbury as much as the opportunity to pillory the Earl of Danby. Members of the House of Commons expressed their hostility to Danby by voting that the money voted for the disbandment of the army be distributed by the Chamber of London, rather than by the Exchequer, the province of Lord Treasurer Danby. ${ }^{47}$ An opportunity to bring down the powerful earl soon presented itself to Danby's opponents. Mid-December brought a scandal which rocked the nation and which finally allowed Shaftesbury to enlarge the scope of his attack to include both Catholicism and arbitrary government.

Deep animosity existed between Danby and Ralph Montagu, the English ambassador to the court of Louis XIV. Montagu blamed Danby for his failure to obtain the Secretaryship of State. As long as the two men were required to work together, their enmity was held in check. Once Montagu lost his place in the king's affairs, he released the full force of his fury against Danby. Montagu was a confirmed womanizer. While in Paris he had seduced both Barbara, Duchess of Cleveland (the king's former mistress) and her daughter by Charles, Anne, Countess of Sussex. The discovery that Montagu was dallying with her daughter infuriated Barbara, who indignantly complained to Charles of Montagu's debauchery of their daughter.

\footnotetext{
47 Burnet, History, pp. 173-174.
} 
Montagu crossed to England to defend himself against Barbara's accusations, and Charles dismissed him for leaving his post without permission. 48

Montagu had prepared himself for such a day by caching away incriminating correspondence between Charles II and Louis XIV. He sought to expose these letters, written by Danby at Charles's command, in order to end Danby's political career. Montagu first got himself elected to Parliament and thus won immunity for the attack he intended to launch against Danby. Surmising Montagu's intentions, Danby hastily summoned William Temple from Holland to run against Montagu for a vacant seat in the House of Commons. After defeating Temple, Montagu quickly turned his attention towards effecting the ruin of his old enemy.

Danby sensed the unfavorable temper of the House of Commons and attempted to avert the attack by seizing Montagu's papers. Charles sent a message to Commons informing them of his intention of bringing Montagu to trial on the charge of plotting to bring in Catholicism. ${ }^{49}$ The king and Danby hoped to find the incriminating letters among those papers seized as part of the bogus investigation. Once they had destroyed the letters, the charges against Montagu would be dropped for lack of evidence. This scheme failed because the critical letters eluded Danby's search.

${ }^{48}$ Fraser, Royal Charles, p. 365.

${ }^{49}$ Burnet, History, p. 175. 
As the House of Commons angrily decried the seizure of Montagu's papers, Montagu brought forth his evidence. His audience could not have been more receptive. Here was proof positive of Danby's double dealings. In a letter dated March 25, 1678, Danby instructed thenambassador Montagu to offer Louis XIV a guarantee that England would not go to war against France if, in exchange, Louis paid Charles a handsome subsidy. This letter had been written just five days after the king had assented to a bill designed to raise money for a war with France. This revelation made all the more plausible the fears that Charles had a secret understanding with Louis XIV, aimed at restoring England to the Catholic fold and creating an arbitrary government. Sir John Reresby described the fears raised by Montagu's disclosure:

- . to advise the King to take mony to raise an army for warr, and at the same time to treat for mony from France to make a peace, which looked as if a standing army was designed to enslave us at home, not to make warr abroad.

The House of Commons quickly moved from furious denunciation of Danby's conduct to impeachment. Danby's supporters argued that the earl could not be accused of treason, since his actions violated no statute of treason. They pointed out that the king had authorized the writing of the letters, and argued that the king had the right to select anyone he pleased to transmit his orders to his ministers

${ }^{50}$ Browning, Reresby, p. 164. 
abroad. 51 These arguments failed to sway the majority of the members of the House, who voted 179 to 116 that there was sufficient evidence for an impeachment. The Commons passed six articles against Danby. They accused him of usurping royal power by discussing with foreign ministers the possibility of peace with France, without the knowledge of other privy councillors. They charged him with al ienating the government from the people by advising the king to raise an army under the pretense of preparing for war. Commons levelled against Danby the ridiculous charge that he was popishly affected. They asserted that he had alienated Charles from his people by negotiating with Louis XIV for a subsidy. 52

Two days before Christmas, members of Commons carried the impeachment of Danby to the House of Lords. Danby attempted to exonerate himself by claiming that he had acted only on the king's orders. A heated debate followed, but Shaftesbury's arguments against Danby failed to carry the House. The Lords resolved that before they would proceed with the impeachment, the House of Commons must prove that the charges levelled against Danby constituted high treason. The Lords provided further evidence that they were not prepared to abandon Danby. On December 23 they rejected a motion that Danby should withdraw from the House since he stood under the threat of impeachment. ${ }^{53}$ Three days later they expressed their

$$
\begin{aligned}
& 51_{\text {Burnet, History, p. } 177 .} \\
& 52_{\text {Browning, Reresby, p. } 165 .} \\
& 53_{\text {Ashley, Charles II, p. } 239 .}
\end{aligned}
$$


confidence in Lord Treasurer Danby by insisting that money voted for the disbandment of the army be paid into the Exchequer, not the Chamber of London. ${ }^{54}$ on the following day, the Lords voted that Danby should not be committed to custody. 55

The question of Danby's guilt had thrown the two Houses of Parliament into a deadlock. The House of Commons finally had slipped from Danby's control. The obstreperous opposition, which now dominated Commons, on more than one occasion had expressed hostility towards both James and the royal prerogative. Charles believed that it would finaliy be in his own best interest to send them packing. After the recent revelations of royal duplicity, the king's chances of obtaining money from the House of Commons were nonexistent. Worse yet, any close investigation of Danby's career might bring to light other secret negotiations between Charles II and Louis XIV. If the secret clauses of the Treaty of Dover were made public, Charles feared that his tenure on the throne would be threatened. The English would not take kindly to the discovery that their king had promised to declare himself a Catholic and to accept the support of French troops if his subjects proved unwilling to accept his conversion. Accordingly, on December 30 Charles prorogued Parliament.

54 Jones, First Whigs, p. 33 .

$55_{\text {Browning, Reresby, p. } 167 .}$ 
Reresby wrote:

When it was least expected the King proroagued the Parlament to the 4 th of February, some said in favour of the papists, others of the Lord Treasurer, others in defense of his prerogative, which was more 56 then one way invaded by the proceeding of the Commons.

Charles informed his council that he intended to set up a committee to investigate the Plot. By this means he hoped to escape any accusations that he had prorogued Parliament in order to protect Catholics. In spite of this, rumors soon circulated that the king intended to give respite to Catholics condemned for participation in the Plot.

After the prorogation, Charles turned his attention to the problem of money. Louis XIV coldly rejected his appeal for another subsidy. The French king saw no need to ease Charles's financial burden. Pro-Dutch Danby was in disgrace; Charles was at loggerheads with his Parliament. ${ }^{57}$ Little would be gained from playing paymaster to a rival king who could offer nothing substantial in exchange for French largesse.

The search for money led Charles and Danby to negotiate with moderate members of the opposition. After much negotiation, they struck a bargain. The moderates agreed to temper the anticipated Parliamentary attack on Danby, and to secure a vote of supply in the next session. Their price for cooperation was high. Danby

${ }^{56}$ Ibid.

${ }^{57}$ Clyde L. Grose, "Louis XIV's Financial Relations with Charles II and the English Parliament," Journal of Modern History, Vol. 1 (June 1929), p. 199. 
must resign from office, James would be required to leave the country, and the king must dissolve the Cavalier Parliament. On the surface, it appeared that the king had been driven to surrender his prerogative to decide when and if Parliament would be dissolved. This was not the case, for Charles had already decided that this now combative Parliament must go. He hoped that elections would bring more moderate men to the House of Commons, a serious miscalculation, as the coming months would show.

On January 24, 1679, Charles II dissolved the Cavalier Parliament, an end to which Shaftesbury had worked for the better part of a decade. When Parliament next sat the conflict between the court and the opposition would deepen, as Shaftesbury accelerated his campaign to prevent the possible imposition of an arbitrary government. In the coming months Shaftesbury and his associates would assault the most inviolable of royal institutions--the hereditary succession to the throne. 


\section{CHAPTER IV}

\section{THE FIRST EXCLUSION PARLIAMENT}

Shaftesbury continued his campaign to limit the prerogative during the first Exclusion Parliament. The king found the members of the newly elected House of Commons to be most intractable. Their impeachment of Danby brought forth a challenge to the royal right to issue pardons. They further developed the principle that Crown ministers must accept responsibility for unpopular as well as $i 1$ legal executive actions. An election reform bill, proposed in Commons, invaded the prerogative by attempting to limit the life of any Parliament to two years. Charles's hope that the Parliamentary elections would bring more moderate men into Parliament proved unfounded.

A keen competition for seats marked the Parliamentary elections of February, 1679. The intensity of the competition was caused not by any political issues, but by the fact that it had been eighteen years since the last general election. Many of the members elected in 1661 had long since abandoned any effort to maintain the support of their electorate. Their base of support had dwindled from neglect. With the sudden calling of new elections, members faced competition from a new generation of aspiring politicians. The furor caused by the outbreak of the Popish Plot and the revelations of the Crown's secret dealings with Louis XIV did nothing to aid ' 
in the re-election of court dependents. Still, exclusion was not a telling issue in the elections of early 1679; the elections were determined by local interests.

Charles II made a serious error in judgment when he predicted that the new elections would bring a more temperate body of men to the House of Commons. Over 320 seats in the House changed hands. In an attempt to assess the strength of the opposition, Shaftesbury carefully studied the results of the election and divided the members into four categories. One hundred fifty three members Shaftesbury classified as old and worthy and 149 as new and honest. By this reckoning, the opposition could count on 302 supporters in the House. Shaftesbury estimated the court to have only 158 supporters in Commons, of which he labelled 98 old and vile and 60 new and bad. 58 His estimations of the opposition's strength in the spring of 1679 proved to be overblown, for he judged members on their antipathy towards Danby rather than on their support for exclusion. In this first round of the contest over exclusion, many men Shaftesbury counted on as supporters would abstain from voting on the Exclusion Bill. Despite the reluctance of some members to vote for exclusion, the opposition held a commanding majority in the newly elected House of Commons.

${ }^{58}$ Election analys is in Browning, Reresby, pp. 169-170; Haley, First Ear 1, P. 500; Jones, First Whigs, pp. 36-48; J.R. Jones, ed., The Restored Monarchy, 1660-1668 (London: MacMillan Press, 1979), pp. 56-57; and E. Lipson, "Elections to the Exclusion Parliaments, 1679-1681," English Historical Review, Vol. 28 (1913), pp. 59-85. 
Charles took steps to conciliate the opposition and to forestall the anticipated attack on Danby and James. Charles asked Secretary of State Williamson for his resignation, an action by which Charles hoped to gain two advantages. Since his detention in the Tower during the previous session of Parliament, Williamson had been so overawed by fear of the Commons that he had lost much of his effectiveness. The king needed a secretary of state on whom he could rely to carry out his orders. If a man could be found for the post who also stood in the good graces of most members of the opposition, the king's hand would be considerably strengthened. Such a man was Robert Spencer, the Earl of Sunderland. Although he privately supported the policies of Danby, Sunderland counted several leading members of the opposition among his friends. He was a nephew of Shaftesbury and the brother-in-law of Lord Hal ifax, who was still considered a member of the opposition. 59

Three days before the new Parliament met, Charles sent James to Brussels. Danby persuaded the king that James's presence in England would further inflame the members against him. He argued that if Charles and Parliament could not come to an agreement, members could not then blame James for the lack of accord. ${ }^{60}$ James left the country with great reluctance. On the day of his departure

${ }^{59}$ J.P. Kenyon, Robert Spencer, Earl of Sunderland (London, New York, and Toronto: Longmans, Green and Company, 1958), p. 23.

${ }^{60}$ Burnet, History, p. 197. 
James wrote to the Duke of Ormonde:

- . you may easily believe, that I take even less pleasure in going out of England than I did in making so insjgnificant a figure, as I have done for some time past.

The Duke deepy regretted his inability to persuade Charles to take stern measures against Shaftesbury and his confederates. Never one to sacrifice principle on the altar of expedience, James urged Charles to dissolve the new Parliament, secure the Tower, and arrest Shaftesbury and his allies. Reluctant to provoke a civil war, Charles instead chose to send James out of the fray. As a concession to his indignant brother, Charles publicly stated that he had never been married to anyone other than Queen Catherine. By this Charles hoped to reassure James that he was not being abandoned in favor of the Duke of Monmouth, the king's bastard son, whose pretensions towards the Crown had long grieved James. 62

Charles opened Parliament on a conciliatory note, listing all of the actions he had taken to win their favor. He reminded them of all he had done to protect England from the dangers of Catholicism, claiming credit for consenting to a new Test Act and for the execution of several participants in the Popish Plot. He declared that James had been sent abroad in order to assure that the king received no Popish counsels. ${ }^{63}$ The king's speech failed to win the

${ }^{61}$ Lady Burghclere, The Life of James, First Duke of Ormonde, 1610-1688, 2 vols. (London: John Murray, 1912), Vol. II, p. 286.

${ }^{62}$ Edward Maunde Thompson, ed., Correspondence of the Family of Hatton, 2 vols. (Camden Society, 1878), Vol. I, p. 177.

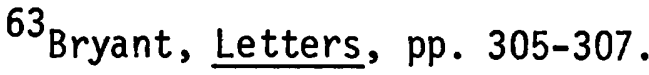


House of Commons to the king's cause. Members assured each other that Charles had pursued the Plot with great reluctance, and that all of his actions against Catholics had been grudgingly undertaken.

The king himself soon dispelled the favorable image he was trying to create. Acting on Danby's advice, Charles asserted his prerogative right to reject the Speaker selected by the House of Commons, Sir Edward Seymour. This infuriated the House, who condemned the move as an unprecedented breach of Parliamentary privilege. Not wishing to goad Commons into greater hostility, Charles attempted to settle the matter gracefully by calling for a brief prorogation, after which the House was allowed to select its Speaker.

Shaftesbury's allies in Commons took full advantage of the ill will this incident generated towards Danby and the king. They channeled this animosity into a renewed attempt to impeach Danby. This move against Danby allowed the opposition to play up their proposition that English liberties, as well as religion, were imperiled by the Catholic conspirators' plan to establish an arbitrary government. By calling attention to the dangers of absolutism, the attack on Danby could be turned into a design to limit the royal prerogative.

On March 18 and 19 Shaftesbury argued in the House of Lords that the impeachment proceedings against Danby were unaffected by the dissolution of the Cavalier Parliament. The Lords voted that within the next week Danby must provide a written response to the charges levelled against him. 
Charles's attempt to put the question of Danby's culpability behind them ironically broadened the conflict to include the pardoning power. He stunned the members by announcing that, since the incriminating letters had been written by his order, he intended to pardon Danby. Parliament should proceed with public business and abandon all plans to impeach Danby. The use of his pardon to prevent impeachment would nullify Commons' right to impeach a minister. The House of Commons quickly rose to the challenge and attacked the validity of the king's pardon.

Sir Francis Winnington echoed the sentiments of most members when he declared:

The King cannot pardon treasons against the government, for then the government cannot be safe against evil ministers. - . If ministers are to be pardoned for the wrongs they do, there is no security, and our pretended free and legal government is a mere cheat.

The two Houses of Parliament disagreed over how to proceed. The Lords resolved not to condemn Danby's pardon until his lawyers had the opportunity to defend it. The members of Commons were equally determined to deny the validity of the pardon and to bring Danby to trial. The House of Lords voted a bill of banishment against Danby, which the House of Commons rejected as entirely too lenient. Commons sought to vote a bill of attainder against Danby, and for several weeks the two Houses were deadlocked. Finally, on April 14, the Lords voted for an amended bill of attainder, which was much less harsh than the Commons' bill.

${ }^{64}$ Roberts, Growth, p. 220. 
On April 16 Danby surrendered himself into custody and was committed to the Tower. Following the king's instructions, he pleaded his pardon when taken before the bar of impeachment on April 25. The House of Commons responded by denying the validity of the pardon and demanding that the earl be put on trial.

In their eagerness to bring Danby to justice, the House of Commons encroached upon privileges which by right belonged to the House of Lords. Commons demanded that arrangements for Danby's trial be made by a Committee of Both Houses, rather than by the Lords alone. The House of Commons next attempted to blackmail the Lords into abandoning the bishops right to vote on the validity of Danby's pardon. The members of the House of Commons realized that the bishops would vote as the king directed, and so declared that they would not attend the trial of the five Catholic peers until the bishops were denied the right to vote for the pardon. Goaded beyond endurance by this assault on their privileges, the House of Lords voted 65 to 36 to stand by the right of the bishops to vote on the question of Danby's pardon. ${ }^{65}$ When Charles prorogued Parliament on May 27, the two Houses were again deadlocked over the question of what to do with Danby. The unfortunate earl spent the next five years in the Tower.

The attack waged against the Earl of Danby in the spring of 1679 represented an assault on the monarchy as well as upon an unpopular minister. During their defense of their right of impeachment, 
the House of Commons directly challenged the king's prerogative to issue pardons, a power Burnet described as:

. . a main article of the King's prerogative: none had ever yet been annulled: the law had made this one of the trusts of the government, without any limitation upon it. 66

of even greater importance than the attack on the royal prerogative to issue pardons, was the justification the House of Commons used as the basis of their onslaught on Danby. The Commons censured Danby, not for committing an illegal act, but for committing an unpopular one.

The House of Commons had long since adopted the principle that ministers of state should refuse to obey any unlawful commands given them by the monarch. Operating under the legal maxim that the king can do no wrong, Parliament forced the Crown's ministers to bear responsibility for any illegal acts that the king ordered them to commit. The impeachment of the Earl of Danby witnessed the birth of a new constitutional principle--the tenet that ministers of the Crown must bear responsibility for unpopular as well as illegal acts. Danby defended himself during his impeachment by maintaining that he had violated no law in writing the letters to Montagu. This was correct, for the king had every right to bargain with Louis XIV for a subsidy and to prorogue Parliament at will. Moreover, it was well known that Danby was no friend to France, and that he negotiated with Louis XIV out of duty rather than conviction.

${ }^{66}$ Burnet, History, p. 201. 
These arguments did not sway the House of Commons from its determination to impeach him. 67

The consequences of Commons' resolution to punish ministers who performed unpopular tasks were far-reaching. If the king could not persuade his ministers to perform unpopular acts, he soon found that they often could not be accomplished. According to the law, the king could perform no ministerial act. Fearful of reprisal from the House of Commons, Lord Chancellor Finch in March 1679 refused to obey the king's order to put the Great Seal to Danby's pardon. Charles attempted to circumvent this difficulty by taking the Seal from Finch and ordering a menial servant to apply it to the pardon. ${ }^{68}$ The House of Commons denounced the pardon as irregularly obtained. By expanding the scope of ministerial responsibility during their attack on Danby, the House of Commons impaired the king's ability to exact obedience from his ministers and curtailed his capacity to act in opposition to the will of Parliament. Sacheverell had this in mind when he declared:

I am not of the opinion that to remove Ministers from the King will better our condition, unless those maxims of state they govern by be removed. 69

Parliament turned its anger at Danby into an attack on his associates, another encroachment upon the king's prerogative to retain ministers at his own discretion. Shaftesbury took the

\author{
67 Roberts, Growth, p. 218. \\ 68 Ibid., p. 225. \\ ${ }^{69}$ Sitwel1, First Whig, p. 58 .
}


offensive in the House of Lords by launching another assault on the Duke of Lauderdale. In an emotional speech, Shaftesbury asserted that under Lauderdale's management Scotland was rapidly going downhill to absolutism. He assured his audience that in Scotland slavery was to come first, to be followed by the introduction of Popery. In England, he warned, it was to be the other way around. 70 On May 6 Parliament voted another address against Lauderdale.

Parliament made other intrusions into the royal prerogative in the spring of 1679. An election reform bi11, introduced on March 26, directly challenged the king's right to control the calling, prorogation and dissolution of Parliament. Danby's management of the Cavalier Parliament taught members the dangers of a longstanding Parliament. The bill stated:

- . no Parliament shall hereafter have Continuance in any manner, by Prorogation, or Adjournment, or Session .. . for above the space of two years . . by at the end of two years shall be ipso facto dissolved.

The king's right to control the timing of Parliamentary sessions constituted a chief weapon in the royal arsenal. In denying him the power to retain a complaisant Parliament, the House of Commons sought to disarm him. The bill received a second reading on April 5.

Commons expressed its hostility towards the monarchy in other ways. In order to deny ministers bribe money, the House demanded $70_{\text {Fraser, Royal Charles, }}$ p. 372.
$71_{\text {Jones, First Whigs, }}$ p. 54. 
that all grants of supply be strictly appropriated. They sought to take precautions which would prevent another army from ever being raised without their consent. They went so far as to suggest that the royal guards be replaced by detachments of the militia. ${ }^{72}$ The House of Commons was determined that neither the king nor his ministers would possess the ability to establish an absolute government. Inevitably members turned their eyes to the heir to the throne, the man Shaftesbury labelled "the chief agent of arbitrary government in England."

Charles took steps to forestall the expected attack on his brother's right to succeed him. In an effort to win over leading members of the opposition, he offered them positions in the restructured Privy Council. He hoped to sow dissension between the leaders and the rank and file members of the opposition, who would worry that in accepting office from the king, their leaders had gone over to the enemy.

On April 21 Charles announced the creation of a new Privy Council. The new Council contained thirty members; of these, fifteen were officers of the Crown and fifteen were men who held no office under the king. Of the fifteen councillors who were not officers of the Crown, ten were to be nobles and five commoners. ${ }^{73}$ The king publicly declared that he would govern, "by the constant

72 Ibid., p. 53.

73 Edward Raymond Turner, "The Privy Council of 1679," English Historical Review, Vol. 30 (April 1915), p. 252. 
advice of such a council. . together with the frequent use of his great council of Parliament." 74 Privately, Charles confided to his friend the Earl of Ailesbury, "God's fish, they have put a set of men about me, but they shall know nothing." 75

The king had good reason to be alarmed by Parliament's intentions. The debate in the House of Commons on April 27 witnessed a critical development in the campaign against a Catholic heir. On that day their condemnation of Catholicism was transformed into an onslaught on James. For the first time, he was openly attacked in Parliament. The debate began with members considering how best to preserve the king from Catholic conspiracies. In order to dissuade Catholics from killing the king in hopes of seeing James restore Catholicism in England, Colonel Birch moved, "That a Bill may be brought in, that at the fall of the King by any violent stroke (which God forbid!) no person come to the Crown of England till that be examined."76 Although the House did not yet move to exclude James from the succession, the members clearly expressed their fears that the Catholicism of the heir was a source of danger. The

${ }^{74}$ Homer E. Woodbridge, Sir William Temple, The Man and His Work (New York: Modern Language Association of America, 1940; reprint ed., New York: Kraus Reprint Corporation, 1966), p. 194.

${ }^{75}$ Ashley, Charles II, p. 249.

${ }^{76}$ Grey, Debates, Vol. VII, p. 145. 
debate ended with the passing of the following motion:

That the Duke of York being a Papist, and the hopes of his coming such to the Crown, have given the greatest countenance and encouragement to the present conspiracies and designs of the Papists against the King, and the Protestant Religion.

The passing of this motion pointed the way towards exclusion. Charles made another bid to prevent the House of Commons from passing a bill to disable James from succeeding to the throne. On April 30 Charles appeared before the House of Lords to repeat his readiness to secure English liberties and religion by paring the nails of a Catholic successor. He warned the Lords, however, that this concession must not be construed to mean that he would acquiesce to any scheme "to alter the Descent of the Crown in the right line, nor to defeat the Succession." 78 Lord Chancellor Finch presented the Lords with a detailed description of the limitations that Charles had offered to impose by statute on any Catholic successor. A Catholic king would be denied any ecclesiastical patronage. Posts in the Privy Council, the Chancery and the Courts of Common Law were to be filled with the consent of Parliament. Parliament would also have the right to nominate the Lords-Lieutenants, their deputies and the officers of the navy. In order to assure that a Catholic successor would not attempt to rule without Parliament, the Parliament sitting at the king's death would remain sitting for

$$
\begin{aligned}
& 77 \text { Ibid., pp. 150-151. } \\
& 78 \text { Jones, First Whigs, p. } 64 \text {. }
\end{aligned}
$$


a certain time, or, if no Parliament were sitting, the last Parliament would automatically reassemble. ${ }^{79}$ The House of Commons initially greeted these proposals with great enthusiasm, but much of the enthusiasm waned as men considered the meaning of the proffered limitations .

The king's scheme to sow division within the opposition by appointing some of its leaders to the new Privy Council appeared to bear fruit. The impeachment of the Earl of $\mathrm{Cl}$ arendon in 1667 had taught members of Parliament a valuable lesson--that politicians often attacked the Crown's ministers in an effort to supplant them in the government administration. They feared that their leaders had abandoned their principles by accepting office from the king. Members expressed this displeasure on May 1 with the introduction of a bill requiring that a writ for a new election be issued whenever a member of Parliament accepted an office or a place or profit from the king. 80

The opposition soon healed this breach within its ranks. By repudiating the limitations scheme, the leaders of the opposition proved that they were not the king's creatures. Commons set May 11 as the day to debate the king's offer of limitations. In the course of this debate, the opposition moved explicitly for exclusion. The debate opened with Bennet proposing that the House address the king not to allow James to return to England without

$$
\begin{aligned}
& { }^{79} \text { Tanner, Conflicts, pp. } 243-244 . \\
& { }^{80} \text { Jones, First Whigs, p. } 63 .
\end{aligned}
$$


the consent of Parliament. Other members of the opposition dismissed this as an inadequate protection against James. Sir Thomas Player put into words the idea that had been gaining support throughout the session when he moved, "That he may be excluded from the Crown of England, and all Papists whatsoever (as I am sure they may be) by Law." 81

Court leaders gained a false sense of security from the fact that more speeches were made in opposition to exclusion than in support of the proposal. They hoped to press their advantage by forcing a division, requesting that those who supported the motion for exclusion go out of the chamber to be counted. Much to their horror, a great many members leapt to their feet and hastened out of the chamber. Realizing that a vote would not be to their advantage, the court members refused to be counted. 82 This hastily contrived challenge to the proponents of exclusion backfired and heartened those who hoped to el iminate James from the succession.

Shaftesbury and his allies were quite correct in their determination to reject the king's offer of limitations, for it is inconceivable that Charles ever seriously considered implementing such a widespread abrogation of royal authority. Shaftesbury had seen firsthand the resistance Charles II had offered to Parliamentary attempts to encroach upon the royal prerogative in the $1670 \mathrm{~s}$. A

\footnotetext{
${ }^{81}$ Grey, Debates, Vol. VII, p. 240.

82 Jones, First Whigs, p. 66.
} 
king who had chided members of Parliament each time that they tried to exercise undue influence over foreign policy, the retention of ministers and the duration of Parliamentary sessions, would never accept legislation that would appreciably curtail the power and the prestige of the monarchy.

Charles had once expressed his distaste for the sort of restrictions upon the authority of the king which acceptance of limitations would bring. He told the Earl of Essex that

. . he did not wish to be like a Grand Signior, with some mutes about him and bags of bowstrings to strangle men as he had a mind to it; but he did not think he was a king as long as a company of fellows were looking into all his actions, and examining his ministers as well as his accounts. 83

Shaftesbury held Charles II in little respect, believing that his brother, his ministers and his mistresses too often influenced his decisions. The king's indolent appearance deceived Shaftesbury. He believed that the real danger to English liberties came from James, who often goaded his tractable brother into resisting Parliamentary attempts to win a greater voice in the governing of English affairs. Thus, Shaftesbury described James's intentions:

His interest and designs are to introduce a Military and Arbitrary Government in his brother's time; which can only secure a man of his Religion a quiet possession of his Beloved Crown.

Shaftesbury did not realize that his greatest adversary was the king, who possessed the cunning and determination necessary to ${ }^{83}$ Tanner, Conflicts, p. 233. 84 Jones, First Whigs, p. 69. 
defeat exclusion. Shaftesiury hoped to channel the fury caused by the "discoveries" of the Popish Plot into an overpowering national demand for the exclusion of Catholic James from the succession. Convinced that the easy-going king must give way in the face of such an overwhelming demand, Shaftesbury refused to consider any other option. He underestimated Charles II's resolution and the weapons at the king's disposal. In the meantime, Charles declined all temptations to forcibly suppress the opposition, an action which would have provoked a civil war. Instead he took pains to appear conciliatory and he offered concessions, albeit in bad faith.

Shaftesbury saw several reasons for declining the king's offer of limitations. Despite his protestations that he would be willing to legally limit the powers of a Catholic successor, the king would find it easy to obstruct the passage of such legislation. Enacting a series of statutes restricting the powers of a Catholic king would require much arduous legislation. Once a bill passed the House of Commons it must go to the Lords for approval. Here the court majority could either reject it or amend it beyond recognition, as happened to the Test $B i 11$ in the previous session. If by some chance a distasteful bill appeared bound for approval in Lords, the king could kill the offending bill by means of a prorogation.

Even if the statutes of limitations passed both Houses and received the king's approval, it was doubtful if they would be legally binding on the Catholic successor. James might shrug off 
all such restrictions by utilizing his suspending or dispensing powers. 85 This point arose when the House of Commons debated the king's proposed limitations. Sir Nicholas Carew argued against the limitations, "I should be glad to be shown any bonds and fetters, that a Prince, when he comes to the Crown, shall not easily break." 86 With greater eloquence Richard Hampden contended:

For us to go about to tie a Popish Successor with Laws for preservation of the Protestant Religion, is binding Samson with withes; he will break them when he is awake. 8

Sacheverell asserted that the limitations would be valueless unless they came into operation during Charles II's lifetime. This confirmed Charles in his conviction that his opponents sought far more than the simple removal of James from the line of succession. The king believed that if exclusion became law, Parliament would arrogate all royal prerogatives under the pretense of maintaining exclusion. 88

For many reasons, then, an Exclusion Bill would suit Shaftesbury's purposes far more than would legislation limiting the powers of a Catholic king. Exclusion could be accomplished by one piece of legislation. If Commons passed the bill when anti-Catholic hysteria was at its greatest, the king would not dare to either obstruct its passage in Lords or to refuse to assent to it. Furthermore, an

${ }^{85}$ Jones, Country and Court, p. 208.

${ }^{86}$ Grey, Debates, Vor. VII, p. 238.

87 Ibid., p. 243.

${ }^{88}$ Sitwel1, First Whig, p. 67. 
Exclusion Bill would offer as many opportunities for limiting the royal prerogative as would the more straightforward statutes of limitations. Exclusion challenged the very foundations of royal authority by implying that the king derived his title to the throne, and therefore his authority and his powers, from Parliament. If this were the case, Parliament possessed the authority to abridge and define the royal prerogative as it saw fit.

In an attempt to justify their effort to dictate the succession, members of Parliament scoured the history books searching for precedents for Parliamentary interference with the succession. They often indiscriminately applied these precedents to the problem of James's succession. As a result, members airily assured each other that they were acting in accord with established custom. In actuality they twisted history to their own purposes. They exaggerated the importance of Parliament in determining the title to the Crown. During a debate in the House of Commons on April 27, 1679, Sir Richard Cust described Henry VII's accession with these words: "But his greatest strength to the crown was not by his match with the Lady Elizabeth, but by declaration of his title by Parliament." 89 Sir Richard considerably amplified the role Parliament played in the first Tudor monarch's accession to the throne. Henry VII was king by right of conquest. By granting Henry a Parliamentary title to the throne, the cowed Parliament did nothing more than confirm a fait accompli.

${ }^{89}$ Grey, Debates, Vol. VII, p. 142. 
Members of the opposition turned most frequently to the Tudor period in their search for precedents. In examining the reigns of Henry VIII and Elizabeth, members of the opposition discovered several instances where Parliament regulated the succession to the throne. Their joy at unearthing such precedents blinded them to the fact that this Parliamentary adjustment of the succession took place under strong monarchs, who directed complaisant Parliaments to regulate the succession to the monarch's advantage.

During the reign of Henry VIII, Parliament thrice enacted legislation altering the succession, each time under the close supervision of the king. In 1534 Parliament declared the king's marriage to Katherine of Aragon void and entailed the Crown on the issue of his marriage to Anne Boleyn. Following the fall from favor of Anne Boleyn, Parliament passed an act in 1536 declaring void both of Henry's first two marriages and entailing the crown on the issue of his third marriage to Jane Seymour. Mary and Elizabeth, respectively the daughters of his first two unions, were declared illegitimate. In default of issue from his third marriage, Parliament gave Henry the power to name his successor. A third Succession Act in 1544 placed Mary and El izabeth back in the line of succession after the lawful issue of the king and Prince Edward. If the king's three children failed to have children, the throne would go to the descendants of his sister Mary. 90

${ }^{90}$ Taswel 1-Langmead, Constitutional, pp. 560-562. 
The statute enacted early in Elizabeth's reign which declared it high treason to deny Parliament's right to regulate the succession held special interest for Shaftesbury and his allies. ${ }^{91}$ Sacheverell made frequent reference to this act during debates on exclusion. ${ }^{92}$ Once again, the opposition enhanced the role of Parliament in the passage of this legislation. The Elizabethan Parliament had enacted this statute under the supervision of a monarch who sought to use Parliament to strengthen her hand against rival claimants to the throne.

The opposition carefully made no mention of James I's accession to the throne, for the first Stuart king came to the throne in direct violation of Parliamentary statute. According to the Succession Act of 1536, Henry VIII could devise the Crown on any person he wished. In accordance with this Act, the Crown had been devised on the descendants of the king's youngest sister. James I was a descendant of Henry's elder sister Margaret. We see here the triumph of hereditary descent over Parliamentary statute, hardly an occurrence to which the opposition would direct attention.

Supporters of the court also made use of precendents in their struggle against exclusion. They pointed to Elizabeth's resistance to all of Parliament's efforts to force her to name her successor. ${ }^{93}$ Despite the determination with which both sides pursued their

\footnotetext{
91 Ibid., p. 593.

${ }^{92}$ See Footnote 39.

93Lipson, "Elections", p. 78.
} 
search, the presentation of the most persuasive historical precedent did not decide the Exclusion Crisis.

Three days after a bill disabling James from succeeding to the throne was proposed, Charles sent a message to the House of Commons. He warned the members that the navy was in a deplorable condition and urged them to vote supplies to build up the fleet. The House dismissed the king's request as a transparent attempt to divert them from their attack on James. Members voted that no money would be given to the king until the succession was changed, religion secured and all officers whom they disliked removed from the kingdom. 94

Al though there might have been an element of calculation in the timing of the king's request, Charles had a genuine need for money. The Crown was delinquent in paying the salaries of officers of state and the household. No money could be found to disband the army, while the magazines stood empty and the garrisons were in disrepair. Commons had no desire to ameliorate the situation. Reresby described members' attitudes towards the king's predicament with these words:

. . the Parlament or the major part in a ferment, glad of thes publique devisions that they might the better clip the prerogative, lessen monarchy, and carry on their private designs. 95

The Exclusion Bill received its first reading on May 15. The bill stipulated that the Crown should descend as if James were

94 Browning, Reresby, p. 180.

95 Ibid., p. 181. 
dead. He was to be banished forever from England and if he ever returned he would be immediately arrested. Any person who insisted on upholding James's right to succeed would be judged guilty of high treason. 96

On May 21 the bill passed on its second reading by a vote of 207 to 128. One hundred seventy members abstained from voting. The leaders of the opposition realized that the Exclusion Bill would not meet with a favorable reception from the House of Lords, so they put off the third reading while they attempted to consolidate their position. Ill will still existed between the two Houses over the question of the bishops' right to vote in capital cases. Shaftesbury and his allies sought to rekindle fury over Danby's negotiations with Louis XIV, his political patronage, and the dangers of the Popish Plot. ${ }^{97}$ They then hoped to channel this anger into support for the Exclusion Bill.

Secretary of State Sunderland, Lord Treasurer Essex, and Privy Councillor Halifax hoped to persuade the influential Shaftesbury to come to terms with the king. They approached him with an offer to join the small and influential cabinet council, but discovered that he sought no compromise with the king. Angry at finding him so intractable, the three ministers urged Charles to prevent passage of the bill by proroguing Parliament. 98

${ }^{96}$ Sitwe11, First Whig, p. 68.

97 Jones, First Whigs, p. 73.

${ }^{98}$ Russe11, Life of Russe11, p. 161. 
This advice concurred with the king's inclinations. On May 27, before the third reading of the Exclusion Bill, Charles appeared before the two Houses and prorogued his first Exclusion Parliament. This body of men would not sit again, for on July 12 the king dissolved Parliament.

On the day of the prorogation the king gave his assent to what contemporaries considered a minor piece of legislation, the Habeas Corpus Act. The act required that there be no delays in granting a writ of Habeas Corpus, which required a jailer to produce reasons for an accused person's detention. The act ignored the question of which courts had the right to issue a writ of Habeas Corpus. The act also did not challenge the king's prerogative to imprison men by means of a royal warrant. Charles apparently looked upon the act with some favor, hoping that it would afford some protection to Danby and the five Catholic peers imprisoned in the Tower. 99

The Habeas Corpus Act may not have been intended as an attack on the royal prerogative, but other actions of the first Exclusion Parliament reveal the opposition's determination to curtail the monarch's powers. The impeachment of the Earl of Danby for obeying the king's lawful commands gave evidence of a new theory of ministerial responsibility, one which boded $i l l$ for the ability of the king to exact obedience from his ministers. The proposal that no Parliament

${ }^{99}$ Fraser, Royal Charles, pp. 379-380. 
be allowed to exist for longer than two years directly challenged the fundamental prerogative right of the king to determine the duration of Parliamentary sessions. It is, or course, the proposal of the first Exclusion Bill which revealed the opposition's hostility not only to Catholicism, but to the unrestrained exercise of the royal prerogative. The bill would undermine the foundations of monarchy, and allow for a much-needed reassessment of the roles of king and Parliament in the governing of England. 


\section{CHAPTER $V$}

\section{THE LINES HARDEN}

Seventeen months elapsed between the prorogation of the first Exclusion Parliament and the opening session of the second. Neither|Shaftesbury nor Charles remained idle during these months, for both realized that the opening of another Parliament would see a renewal of the contest over exclusion.

Following the prorogation of Parliament on May 27, the task of administering the government fell into the hands of three men, the so-called Triumvirate: Lord Halifax, Lord Treasurer Essex and Secretary of State Sunderland. They shared a deep concern over Shaftesbury's increasing ascendancy over the opposition, especially since the earl had sworn to have the heads of the men who advised the prorogation.

A potentially dangerous rebellion in Scotland faced the king during May and June. Provoked by Lauderdale's maladministration and Archbishop Sharp's attempt to convert the Presbyterians to the Church of England, the Covenanters rose in rebellion. They seized and murdered the archbishop and defeated a government force sent to subdue them. Fortunately for the king, the rebels fell to bickering among themselves. Immobilized by internal dissent, the rebels posed much less of a threat. They met with defeat on 
June 22 at Bothwell Brig, at the hands of a large English force under the command of the Duke of Monmouth.

This victory over the Scottish rebels catapulted Monmouth into the English political arena. The Protestant duke was now the darling of the masses, acclaimed as a hero by the lower classes of London. The popular enthusiasm for the king's illegitimate son threw the members of the Triumvirate into a panic. They feared that Shaftesbury would unite his political goals with Monmouth's ambition and present the duke as the exclusionists' candidate for the position of heir. ${ }^{100}$ Accordingly, they pressed the king to dissolve Parliament before the triumphant Monmouth returned to London.

These fears proved to be ungrounded, for, al though Shaftesbury flirted with the idea of putting forward Monmouth, he never committed himself to supporting the duke's ambitions. Monmouth may have been the favorite of the common people, but most influential men found that the prospect of placing the king's illegitimate son on the throne left a bad taste in their mouths. He drew his supporters from two very diverse groups, the lower class and the court. In addition to his friends, Monmouth counted as his supporters a circle of debauched young courtiers who hoped to attach themselves to a rising figure in the political sphere. 101

100 Kenyon, Sunderland, p. 27. 101 Jones, First Whigs, pp. 14, 81, 82. 
The prospect of the Duke of Monmouth succeeding to the throne horrified the king's ministers. They began to look with favor on the more likely alternate candidate for the Crown, William of Orange, the Protestant husband of James's eldest daughter Mary. Sir William Temple, the former ambassador to The Hague, and currently a leading councillor, stood high in the favor of the Prince of Orange. On June 1, Charles had appointed another councillor, Henry Sidney, to be the new envoy to the United Provinces. Charles told Sidney that he had been selected because William regarded him with such goodwi11.102

The members of the Triumvirate also preferred William to Monmouth. They hoped that by making an alliance with the Dutch, the king could discharge the accusations that he secretly sympathized with the policies and governing principles of Louis XIV. Even if exclusion failed, William would very likely one day sit on the throne of England as King Consort to James's heiress Mary. They hoped that their pro-Dutch policy would keep them in william's good books.

Shaftesbury never committed himself to Monmouth's pretensions, but neither did he attempt to link his fortunes to that of William of Orange. Shaftesbury had resolved to exclude James from the succession, yet he did not champion either of the likely alternatives

${ }^{102}$ Henry Sidney, Diary of the Times of Charles II, edited by

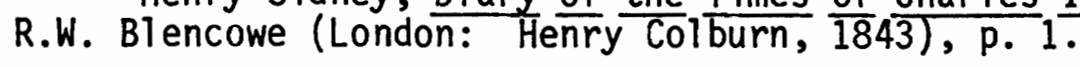


to James. Putting the bastard Monmouth forward as substitute heir would alienate many people who might otherwise have supported exclusion. Giving his blessing to the candidacy of William and Mary also involved many dangers. Mary might refuse to usurp her father's place in the line of succession. Even if she expressed willingness to step into her father's shoes, the exclusionists did not relish the idea of England coming under the sway of Dutch William, for they did not like the man. William was, after all, a Stuart (the nephew of Charles and James). He possessed the same high concept of kingship which so plagued Parliament throughout the seventeenth century. Although he was a Protestant, his adherence to Presbyterianism would not find favor with England's Anglicans. 103 Moreover, William's preoccupation with his struggle against Louis XIV meant that he would always give precedence to the requirements of his anti-French campaign on the continent. Exclusionists feared that William would sacrifice English political liberties in order to facilitate his campaign against France. 104

The fact that Shaftesbury fought tooth and nail for exclusion, even though he saw no attractive alternative to James, indicates Shaftesbury's conviction that James posed the greatest possible threat to English liberties. Furthermore, if William and Mary came to the throne on the basis of an Exclusion Bill, the nature

${ }^{103}$ Stephen B. Baxter, Will iam III and the Defense of European Liberty, 1650-1702 (New York: Harcourt, Brace, and WorTd, Inc., 1966), pp. $165-166$.

${ }^{104}$ Haley, First Earl, p. 465. 
of their title to the Crown would vitiate many of William's authoritarian tendencies. If William held the throne by Parliamentary title, he could not claim that Parliament lacked the authority to limit his prerogatives. Shaftesbury clearly believed that an Exclusion Bill would permanently alter the nature of the English monarchy, leaving the king forever dependent upon Parliament. For this reason, the aging and sickly Shaftesbury devoted all of his dwindling energies to securing the exclusion of James from the succession.

The members of the Triumvirate believed that Shaftesbury intended to exploit wionmouth's popularity in order to pressure Charles into accepting exclusion. The king heeded their warning and resolved to dissolve Parliament. At a meeting of the Privy Council on July 3 he asked the councillors for their opinions on the question of a dissolution. The majority advised the king not to dissolve Parliament. Three days later Charles confided to Lord Chancellor Finch that he intended to dissolve Parliament against the Council's advice. Instead of offering to support the king's decision, Finch warned Shaftesbury of Charles's intention. 105 Shaftesbury roundly denounced the members of the Triumvirate for advising the king to put an end to the Parliament, but he lacked the ability to prevent Charles from exercising his prerogative ${ }^{105}$ Kenyon, Sunderland, p. 28. 
right to terminate the session. When the Council next met on July 10, Charles tersely informed the group of his intentions and warned them that he would not listen to their objections. Two days later Parliament was dissolved; Charles called for a newly elected assembly to meet on October 7.

This experience provided Shaftesbury with another opportunity to assess the value of the king's promises. When Charles created the new Privy Council in April he had sworn that he would govern by the constant advice of the Council. 106 since then he had relied for advice on a select group of councillors, allowing the Privy Council to play no important role in the ordering of the nation's affairs. Charles made the decision to dissolve Parliament in contradiction of the advice offered by the majority of the councillors. Despite his fulsome promises to rule in cooperation with the influential men of the realm, the king chose to rely upon a small group of favored advisers and to settle disputes by exercising his prerogatives. Shaftesbury would remember this when the king next offered limitations as a substitute for exclusion.

In order to put himself in a position where he need not rely upon grants of supply from a recalcitrant Parliament, Charles in the summer of 1679 reopened negotiations for a subsidy with Lou is XIV!07 These negotiations would continue, off and on, until the spring of ${ }^{106}$ See Footnote 75 . 107 Grose, "Louis XIV," p. 200. 
1681 when the two monarchs finally struck a bargain. In the meantime, Charles instructed the Lord Treasurer to effect whatever economies were necessary for the amelioration of the king's financial situation.

Charles had learned a lesson during the Parliamentary elections of the past February. He realized that the prorogation and dissolution of the last Parliament before the Exclusion Bill had received its third reading had infuriated the exclusionists. He decided that he must influence the electors in order to prevent his opponents from sweeping the polls. To achieve this end, he turned to his Lords Lieutenants, men of considerable importance in the countryside, and to the loyal clergy. ${ }^{108}$ A flood of pro-exclusion pamphlets and newspapers counteracted the clergy's exhortations against exclusion. 109 Concern about James ran so high that Shaftesbury's party won an impressive majority in the House of Commons. Shaftesbury believed that the king's resolution to stand by his brother would crumble in the face of such overwhelming opposition. He underestimated Charles. As Sidney recorded in his diary on August 3, the king "saith he will not leave the Duke, and that they will be both undone together." 110

$$
\begin{aligned}
& 108 \text { Jones, First Whigs, p. } 93 . \\
& { }^{109} \text { Ibid., p. } 95 . \\
& { }^{110} \text { Sidney, Diary, p. } 93 .
\end{aligned}
$$


During the course of the elections, an event occurred which reaffirmed Shaftesbury in his determination to see James excluded from the succession. Without warning, the king fell gravely $i 11$ and appeared to be near death. Shaftesbury and his associates fell into a panic. James's status as heir presumptive was legally untouched. If Charles died before an Exclusion bill passed into law, James would take a great deal of pleasure in wreaking vengeance on the men who had attempted to prevent his succession. The effort to exclude James thus contained an element of self-preservation.

The king's chief ministers had encouraged Charles to keep James in Brussels. His presence would provide unnecessary provocation to the opposition during the elections. As the king hovered near death, the members of the Triumvirate speculated that Shaftesbury and Monmouth would attempt to seize control of the government if the king died. On August 25 the ministers sent a message to James, urging him to return to England. James hastened to his brother's side, but by the time he arrived Charles had taken a turn for the better, and the ministers found themselves faced with the embarrassing problem of persuading the heir to leave the country.

James was not amenable to such persuasion. He blamed the ministers for prolonging his exile and held them accountable for the limitations scheme Charles had proposed during the last session. James's return broke the Triumvirate. Halifax and Essex urged Charles to order James back to the continent, while Sunderland made his peace with James and urged Charles to send Monmouth, 
rather than James, into exile. ${ }^{111}$ In the end, Charles ordered both Monmouth and James to leave the country, al though James received the promise that, if Parliament had not met by January, he would be allowed to return. On September 24 Monmouth left for the Netherlands. Charles moved James's place of exile from Brussels to Edinburgh, where he would act as Royal Commissioner.

Realizing that the elections were going in his favor, Shaftesbury had exploited James's return to England in order to strengthen his hand for the session of Parliament scheduled for October. He sought to re-create panic over the dangers of James's Catholicism. His close associate, Sir Thomas Player, denounced James's presence in London as a danger to the citizens. He insisted that the watch be doubled. 112

Player also manipulated London's mayor into declaring against James, as Charles Hatton recorded in a letter dated September 13, 1679:

It is said Sr Th. Player termed te Duke an enemy to [ye] city, and one who by ye Parliament had been declared soe to ye whole nation, and tooke notice to ye Ld Mayor that it had been reported yt he shou'd have said, had his Maty dyed of his late illnesse, he wou'd immediately have proclaimed ye $D$ [uke] of Y[ork] King; wch ye Ld Mayor denyed, deçlaring he wou'd stand and fall by ye protestant interest.

On October 7 Charles prorogued Parliament until January 1680 , dashing Shaftesbury's hopes for the coming session. By means of a

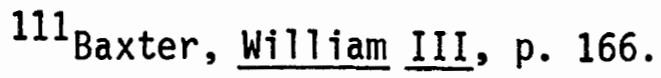

112 Jones, First Whigs, p. 107.

${ }^{113}$ Thompson, Correspondence, Vol. I, p. 195. 
series of prorogations, the Parliament elected in the summer of 1679 did not sit until October of 1680. According to Burnet, the king decided to put off Parliament until the nation's temper grew cooler. ${ }^{114}$ In his diary on November 15 , Sidney recorded a message Charles sent to William: "I am to tell the Prince that the King will prorogue the Parliament, that there was no remedy, that they would have his crown." 115 Charles, of course, could not give this as the reason for his decision. He let out that he was negotiating a treaty with the Dutch and that he did not want to meet Parliament until he could present its members with an Anglo-Dutch treaty. 116

This decision not to call Parliament troubled Essex, Halifax and Temple. As a gesture of protest, Essex resigned from the office of Lord Treasurer and retired to the country. Sunderland grew higher in the king's favor, while Halifax and Temple found their advice increasingly ignored. They soon followed Essex's lead and withdrew to their country estates.

Shaftesbury did not accept the prorogation of Parliament with good grace. Charles hoped to postpone the conflict until the agitation for James's exclusion had subsided. He believed that without a Parliamentary platform Shaftesbury could not keep tempers at a fever pitch. The Earl circumvented the king's plans by launching a nationwide drive for petitions asking Charles to allow

$$
\begin{aligned}
& { }^{114} \text { Burnet, History, p. } 240 . \\
& { }^{115} \text { Sidney, Diary, p. } 187 . \\
& { }^{116} \text { Thompson, Correspondence, Vol. I, p. } 197 .
\end{aligned}
$$


Parliament to assembie. Outside of Whitehall Chapel, on December 7 , Shaftesbury handed Charles a petition, signed by seventeen peers, calling for the immediate summoning of Parliament. ${ }^{117}$ Infuriated at this invasion of his prerogative, Charles informed his Council that not only would he not comply with the petition, he intended to prorogue Parliament until November of 1680.

The members of the opposition organized a nationwide campaign for drafting petitions and collecting signatures. Shaftesbury hoped to generate excitement and support for exclusion by allowing the common man to play a role in the pro-exclusion movement. He planned to show the king the strength of the opposition by presenting Charles with "monster petitions," each bearing the names of tens of thousands of citizens. Shaftesbury persuaded the influential Common Council of London to present a petition. Charles caught wind of their intention, and frustrated Shaftesbury's plan by removing several pro-exclusion councillors who were not qualified under the Corporation Act. ${ }^{118}$

The king sought to thwart Shaftesbury's scheme for maintaining the unity and sense of purpose of the opposition. Charles launched a two-pronged assault on the exclusionists, attempting to discredit his opposition and to assure the nation that his government was soundly pro-Protestant. The king hoped to make clear his displeasure 117 Kenyon, Sunderland, p. 33.
118 Jones, First Whigs, pp. 119-120. 
with the opposition's leadership by dismissing Shaftesbury from his post as Lord President of thhe Privy Council. ${ }^{119}$ He sought to impress his subjects with the realization that the king considered petitions calling for an immediate session of Parliament to be offensive. Accordingly, on December 12 he instructed Lord Chief Justice North to issue a proclamation against "tumultuous and seditious" petitions. 120 charles, however, did everything in his power to encourage his supporters to present addresses decrying the opposition's impertinent reliance upon petitions, and abhorring the petitions as an encroachment upon the royal prerogative.

The winter of 1679-1680 witnessed the polarization of the politically active into two factions, the "petitioners" and the "abhorrers." Each side sought to discredit the other, and the famous epithets each party subsequently adopted as its name developed from this hostility. The petitioners were condemned as being no better than rebels, and their opponents scathingly labelled them Whigs, the name of a group of Scottish rebels. The newly-christened Whigs considered their rivals to be as reprehensible as a group of Irish brigands known as the Tories. They ascribed that name to those who abhorred the petitioning campaign. 121

As part of his campaign to weaken the opposition, Charles set out to remove all Whigs from positions of authority. He hoped to

$$
\begin{aligned}
& 119 \text { Fraser, Royal Charles, p. } 386 . \\
& { }^{120} \text { Sitwel1, First Whig, p. } 74 . \\
& { }^{121} \text { Jones, Restored Monarchy, pp. 58-70. }
\end{aligned}
$$


cripple his opponents by destroying their bases of operation, hence he ordered the loyal Lords Lieutenants to prepare lists of Whig office-holders. During the first half of 1680 , Charles purged Whigs from offices in the localities, from the militia, the magistracy and the lieutenancy. His attempt to purge the boroughs proved less successful, however. The Whigs had often gained a controlling interest in the boroughs and they ignored royal orders to put the Corporation Act into effect. 122

The king's decision to allow James to return to London in February provoked Whig members of the Privy Council to resign. Charles did not regret their departure. When they asked his permission to withdraw from the Council the King readily assented, granting their request, "with all my heart."123 Charles calculated that his attempt to remove Whigs from offices of importance would lead his subjects to speculate that their easy-going king had asserted himself because he perceived that the Whigs threatened royal authority. If his subjects saw exclusion as a mere mask, intended to conceal an attempt to usurp royal authority, he hoped that their loyalty to the Crown would reaasert itself with a repudiation of exclusion.

Charles also hoped to win support by ridding his government of its reputation for being pro-Catholic. In spite of his personal inclinations towards toleration, he allowed his ministers to

122 Jones, First Whigs, p. 121.

${ }^{123}$ Russe11, Life of Russel1, pp. 202-203. 
enforce penal laws against recusants. On the international scene, he sought to win his subjects' approbation by creating a series of anti-French alliances.

His first important step in building a string of Protestant alliances was to prevent the imolementation of a Franco-Dutch alliance. Louis XIV overcame his distaste for the Dutch, and asked them for an alliance, in order to facilitate his campaign against Spain and the Holy Roman Empire. Charles offered William extravagant promises of English aid, ships, and troops, if Louis again turned against the Dutch. ${ }^{124}$ By this means Charles persuaded William to prevent Dutch ratification of a treaty of alliance with France. This opened the way for the creation of an anti-French coalition.

In the spring of 1680 English envoys set out for the capitals of almost every Protestant state in Europe. Envoys were also sent to Louis XIV's Catholic enemies, Spain and the Empire. Sunderland, the mastermind behind the scheme, initiated the plan with high hopes for success. As the months passed, his optimism suffered a severe blow, for however great their antipathy towards France, most European powers were not willing to risk an alliance with Charles II. The continental monarchs realized how strained was Charles's relationship with his Parliament. The English king would be of no value as an ally unless he could provide money and troops for his allies' defense. Charles could not do so without a ${ }^{124}$ Kenyon, Sunderland, p. 41. 
Parliamentary grant of suppply. Parliament was not in session, and even if it were, it obviously would be so preoccupied by the exclusion contest that no grants of supply would be forthcoming. 125 In the end, only the hopelessly weak Spain agreed to sign a defensive treaty with England. The failure of his foreign policy, combined with Shaftesbury's success in holding together his party, persuaded Sunderland that Charles could not resist exclusion.

Shaftesbury refused to become disheartened by the long prorogation. In order to rekindle anti-Catholic hysteria, he invented an Irish plot, complete with plans to take over the government in Dublin and to massacre Ireland's Protestants. Shaftesbury relied upon a tried and true method of arousing English ire. Englishmen's longstanding cultural aversion towards the Irish had, in the sixteenth and seventeenth centuries, united with religious bigotry to form a potent abhorrence of Irish Catholicism. Shaftesbury recruited witnesses who would substantiate his claim that the Irish were about to rise. In April of 1680 he warned the Common Council of London that an uprising was imminent, but that he must reserve the details of it for Parliament. 126

Two events in May of 1680 persuaded Shaftesbury that he must do everything in his power to expedite the opening of Parliament. Another sudden illness of the king brought home the fact that

$$
\begin{aligned}
& { }^{125} \text { Baxter, William III, p. } 126 . \\
& { }^{126} \text { Jones, First Whigs, p. } 124 .
\end{aligned}
$$


James's right to succeed his brother was still legally untouched. Shaftesbury had no desire to remind himself of what would happen if Charles died before Parliament resolved the problem.

The king had also stepped up his offensive against the Whigs. With the blessing of the king, the judges informed the Privy Council that, in their unanimous opinion, the king was entitled to ban unlicensed books and pamphlets. ${ }^{127}$ As a result, Whig journalists and pamphleteers fourd themselves facing charges of seditious libel.

Finally, the signing on June 10 of an Anglo-Spanish defensive treaty (an act which falsely raised fears that other nations might follow suit) goaded Shaftesbury into a very daring act. On June 26 he and several of his followers appeared before the Middlesex grand jury to indict James as a recusant and the king's chief mistress, the Duchess of Portsmouth, as a common prostitute. ${ }^{128}$ Charles intervened, ordering Lord Chief Justice Scroggs to discharge the jury before it received Shaftesbury's evidence.

This open assault upon the king's brother and mistress electrified Europe. The fact that such an audacious act went unpunished confirmed most continental monarchs in their suspicion that Charles was no match for his Parliamentary opposition. The act considerably heartened the Whigs, who assured each other that Shaftesbury wouldn't have dared such an insult to the king unless he was

$$
\begin{aligned}
& 127 \text { Fraser, Royal Charles, p. } 389 . \\
& { }^{128} \text { Kenyon, Sunderland, p. } 49 .
\end{aligned}
$$


confident of victory. Appalled at the realization that she would have been placed in the stocks had Scroggs not intervened, the Duchess of Portsmouth defected to the Whigs. If the Whig leadership would guarantee her immunity from future attacks, she promised to use her influence with the king to persuade him to accept exclusion. All in all, the gamble paid off well for Shaftesbury. It created the impression of strength.

The Duke of Monmouth shared Shaftesbury's optimism. He had apparently convinced himself that he would be his father's heir. After being sent to the Netherlands in September of 1679, Monmouth had slipped back into England without permission late in November. As a result, Charles stripped Monmouth of his offices and pensions. The ecstatic reception offered Monmouth by London's citizens counterbalanced the cold welcome he received from his father. To Charles's displeasure, Monmouth lingered on in London, his spirits buoyed up by the prospect that he might replace his uncle in the line of succession. His friends engaged in a wild search for a mysterious black box, which supposedly contained papers indicating that Charles had married Monmouth's mother. ${ }^{130}$ In order to quell the rumors to this effect that were circulating throughout the country, Charles on June 2 declared again that he had been married only to the queen. ${ }^{131}$ Monmouth's hopes refused to be dashed,

$$
\begin{aligned}
& { }^{129} \text { Ashley, Charles II, p. } 260 .
\end{aligned}
$$

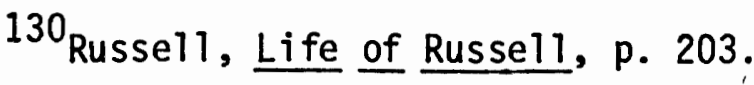

$$
\begin{aligned}
& { }^{131} \text { Kenyon, Sunderland, p. } 49 .
\end{aligned}
$$


however, for in August he made an almost regal tour of the west country.

A widely-read pamphlet, published in 1679, offered encouragement to Monmouth's pretensions. Its author stated:

He who hath the worst titie, ever makes the best King, as being constrained by a gracious government to supply what he wants in title, [so] instead of "God and my Right," his motto may be, "God and my people"

The author clearly recognized the constitutional significance of a Parliamentary title to the throne: such a king must acknowledge that his position and powers were derived from the people and not from God.

In mid-August Charles had decided to allow Parliament to meet on October 21. A foreign crisis, the Moorish assault on Englishheld Tangier, required that a Parliamentary vote of supply be quickly obtained. The king realized that the opening of Parliament would bring a renewal of the attempt to exclude James from the succession, but he was determined not to abandon his brother. In the preceding month, Portsmouth had attempted to fulfill her bargain with the Whigs by acting as an intermediary between the opposition and the king. She had been empowered to offer Charles $L 600,000$ and the right to name his successor if he would agree to James's exclusion. ${ }^{133}$ Charles declined the offer.

132 J.P. Kenyon, ed., The Stuart Constitution, 1603-1688, Documents and Commentary (Cambridge: University Press, 1966), p. 469.

${ }^{133}$ H.C. Foxcroft, A Character of the Trimmer (Cambridge: University Press, 1946), p. 110 . 
Despite this refusal, the Whigs were optimistic that the king would buckle under to their demands. Most ministers and men close to the king believed that James's exclusion was inevitable:

Sunderland, Sidney, Godolphin, Essex, Temple, and Burnet shared this view. 134 Two men hoped to placate the Whigs by renewing the offer of limitations: Lord Treasurer Hyde (James's brother-inlaw) and Halifax, who had rejoined the government in June, were of this opinion.

As he did in the spring of 1679 , Charles ordered James to leave England shortly before Parliament met. As he prepared to leave for Scotland, James asked his brother to publicly pardon him for all offenses he might have committed in the past. Charles refused, believing that such an action might provoke the House of Commons into challenging the validity of the royal pardon, as they had when Charles had pardoned Danby. ${ }^{135}$ The king knew that once Parliament had reassembled, the Whig majority in Commons would immediately move for exclusion, which Charles recognized as an implied threat to his prerogative. By denying James a pardon, the king hoped to forestall any Parliamentary attempt to directly encroach upon his prerogative rights. His effort proved unsuccessful.

${ }^{134}$ Feiling, History Tory, p. 182.

135 F.C. Turner, James II (London: Eyre and Spottiswoode, 1950), p. 182 . 


\section{CHAPTER VI}

THE SECOND AND THIRD EXCLUSION PARLIAMENTS

In the meantime, the $\mathrm{Kg}$ and Duke seeme both in good humour, and, if they will be firm, I beleeve they are safe; and for my own part, I think they cannot but together. For, if he shews he can part with his brother, wht may not be presumed upon after?

Sir Charles Lyttelton, October $12,1680^{136}$

The Second and Third Exclusion Parliaments produced increasingly blatant attacks upon the royal prerogative. The king's staunch opposition to exclusion forced his opponents to attempt to curtail his ability to oppose the will of the nation. Once again, members of the House of Commons challenged his right to issue pardons and attacked his ministers. An even more ominous invasion of the prerogative occurred when the Commons decided to link an Exclusion Bill to the creation of a Protestant Association, an action which would wrest wide powers from the hands of the king.

The House of Commons assembled on October 21 in an atmosphere of confident expectation. Great things were in the offing. Without question, this session of Parliament would witnesss the final struggle between the king and the Whigs over the exclusion from the succession of James, Duke of York. The Whigs felt equal

${ }^{136}$ Thompson, Correspondence, Vol. I, p. 238. 
to the battle. The night before the session opened, many Whigs assembled at the Sun Tavern to celebrate their anticipated victory. They took heart from the fact that James had been sent out of the country and that the king's leading ministers had openly predicted that Charles would abandon James. The rumor circulated that the prospects of the coming session had so dejected the nation's Catholics that they planned to blow up Parliament. ${ }^{137}$

The king's speech to Parliament, however, contained no hint of surrender. He described his alliance with Spain as one of "the best measures that could be taken for the safety of England." He promised his consent to any measures designed to secure the Protestant religion, adding the important qualification that these measures must "consist with preserving the succession of the Crown in its due and legal course of descent." Finally, he asked for a grant of supply in order to defend Tangier, which stood besieged by the Moors. 138

The members of the House of Commons paid scant attention to the king's request for aid for Tangier. They felt that the threat to a Moroccan city was of far less import than the threat James's succession posed to English religion and liberties. Believing that they possessed a mandate to rectify the succession problem, they moved immediately to revitalize the Parliamentary campaign

${ }^{137}$ Cecil Price, Cold Caleb: The Scandalous Life of Ford Grey, First Earl of Tankervi17e, 1655-1701 (London: Andrew MeTrose, 1956), p. 52 .

$138_{\text {Bryant, Letters, }}$ p. 314 
for exclusion.

They first reaffirmed their assertion that a Catholic king could not respect the religion and rights of his Protestant subjects. They accomplished this by dredging up stories of James's complicity in the Popish Plot. ${ }^{139}$ From there it was a short step to the reintroduction of a motion for a bill disabling James from following his brother on the throne. On October 25 Shaftesbury's old ally in the House of Cominons, William Russell, introduced a motion for James's exclusion. On the following day, Commons resolved "to proceed effectually to suppress popery, and to prevent a popish successor." 140

The members of the House of Commons did not permit their struggle for exclusion to preclude the discussion of other grievances. Sacheverell proposed that the House present the king with an address stating their conviction that petitioning the king was an undoubted right of his subjects. ${ }^{141}$ In their anger over Charles's response to the Whig petitions, members expelled several prominent abhorrers from the House ${ }^{142}$ and discussed impeaching Justice North, the author of the proclamation against tumultuous petitioning. ${ }^{143}$

${ }^{139}$ Haley, First Earl, p. 594.

140 Russe11, Life of Russel1, pp. 209-210.

${ }^{141}$ Sitwel1, First Whig, p. 139.

${ }^{142}$ Browning, Reresby, D. 202.

${ }^{143}$ Sitwel1, First Whig, p. 139. 
Continental rulers followed the proceedings of the House with keen interest. Louis XIV was so certain that exciusion would prevail that he ordered his ambassador Barillon to champion the candidacy of William as the lesser of two evils, believing that Monmouth could unite the English better than the foreign-born William could. ${ }^{144}$ For his part, William sent a special representative to England to promote him as an alternative successor should James be excluded. Leyden van Leeuwen frequently met with the king and his leading ministers, often relaying messages between Charles and Will iam. 145

The Whigs rushed an Exclusion Bill through the House of Commons in nine days, proposing it on November 2 and giving it a third reading on November 11 . The Tory members of the House realized that the Whigs held a numerical superiority and they tried to forestall passage of the bill by sowing division among the Whigs. The Whig ranks contained supporters of both William and Monmouth, and the Tories hoped to split Whig solidarity by insisting that the Exclusion Bill name the king's successor. 146 This caused only a temporary setback, however, for both whig factions agreed to state that the Crown should descent as if James were dead. Monmouth's supporters took heart from their belief that, should the bill succeed, it could later be amended in favor

$$
\begin{aligned}
& { }^{144} \text { Baxter, Will iam III, pp. 170-171. } \\
& { }^{145} \text { Ibid. } \\
& 146 \text { Jones, First Whigs, p. } 135 .
\end{aligned}
$$


of Monmouth.

Despite the Tories' arguments against it, the bill passed quickly through the necessary stages of preparation. Secretary of State Jenkins attempted to argue that the bill threatened Charles as well as James:

And this Bill removes the next Prince of the Blood from the Succession. Is there any security that the present Prince 147 may not be in danger of removal, if this Bill should pass?" 147

The Whigs discounted any suggestion that the bill would create an elective monarchy, and declared that the bill would merely prevent the kingdom from falling into the hands of a puppet of the pope. Mr. Trenchard stated a fundamental Whig principle, one as reprehensible to Charles II as it had been to his Stuart predecessors, when he declared, "The King's right to the Crown is by Common and Statute law." 148 This principle was incompatible with the king's concept of the foundation and perquisites of the monarchy.

In the course of preparing the bill, the Whigs once again challenged the king's right to pardon offenses. Charles had sought to prevent this action when he refused to provoke the Whigs by extending a royal pardon to James before the Duke left for Scotland. The Whigs added a clause to the Exclusion Bill rendering the King incapable of pardoning anyone who supported James's claim to the throne, an act of treason according to the bi11. 149 This usurpation

${ }^{147}$ Grey, Debates, Vol. VII, p. 426.

${ }^{148}$ Ibid., p. 458.

${ }^{149}$ Sitwel1, First Whig, p. 139. 
of the prerogative affirmed the king in his belief that under the pretext of maintaining exclusion, the Whigs would curtail Charles II's own prerogatives.

In order to prevent this, Charles on November 9 sent a message to the House of Commons warning the members that he would never assent to the exclusion of his brother from the succession. 150 The king's message did not deter Commons from passing the bill on its third reading. It did clarify the king's wishes to the House of Lords, whose members had been confused by reports that Charles wanted both Houses to pass the bill, so that he could claim that Parliament forced him to assent to exclusion. The Lords now realized that the king did not look to them to provide a gracious excuse for the abandoning of James. They realized that Charles implacably opposed exclusion, and the royalist majority in Lords rallied to the king's cause.

Shaftesbury's optimism about the outcome of the bill proved to be unfounded. He had been convinced that charles would give way to the Whig onslaught and encourage the House of Lords to pass the Exclusion Bill. Shaftesbury attempted to enfuse the Lords with some of Commons' enthusiasm for exclusion. He played up the dangers of Catholicism by recounting details of the fabricated Irish Plot. ${ }^{151}$ Four days elapsed between the passage of the bill in Commons and its presentation to the House of Lords. The Whigs

${ }^{150}$ Russe11, Life of Russe11, pp. 221-222.

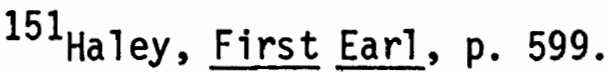


devoted these days to an effort to coerce Halifax into abandoning his opposition to the bill. Despite threats of impeachment, Hal ifax refused to be swayed. 152

Shaftesbury and Halifax dominated the House of Lords' debate on the Exclusion Bill, an exhausting ordeal continuing from eleven in the morning until late at night. They both argued ably and from the heart, but Halifax's eloquence surpassed that of Shaftesbury. No text of the debate has survived, but those present unanimously professed their belief that Halifax carried the day for the king. Burnet declared, " . . he gained great honour in the debate; and had a visible superiority to Lord Shaftesbury in the opinion of the whole house." 153

The House of Lords rejected the Exclusion Bill on its first reading by a vote of 63 to 30 . In spite of Halifax's contribution, the credit for the defeat of the bill must go to Charles II. The king's presence in the upper chamber had overshadowed the debate between Shaftesbury and Halifax. As members voted on the fate of the bill, they were acutely aware that the king's eyes were upon them. A majority of the lords chose not to fail him.

The defeat of the second Exclusion Bill stunned the members of the House of Commons, who just weeks before had been confident of victory. In their anger, they turned upon the man whom they blamed for sabotaging their attempt to protect English religion

${ }^{152}$ Foxcroft, Character, pp. 114-115.

153 Burnet, History, p. 252. 
and liberties--the Earl of Halifax. The members now determined to achieve two goals: the successful renewal of the fight for exclusion, and the destruction of the Earl of Halifax. Shaftesbury resolved that the defeat of the bill would not signal the end of the exclusion movement. This setback merely indicated that he needed to increase the pressure on the king, and this he hoped to accomplish by implementing a policy of systematic obstruction. ${ }^{154}$ The House of Commons must force the king to realize that, unless he abandoned James, the House would do everything possible to render the government incapable of functioning. Faced by the impossibility of conducting the government, the king would allow the House of Lords to acquiesce to Commons' demand for exclusion.

For his part, Hal ifax turned immediately to reviving a policy near to his own heart, the placing of limitations upon any Cathol ic successor. On the day after the House of Lords rejected the Exclusion Bill, the House went into committee to discuss alternative methods of securing the Protestant religion. Halifax lobbied earnestly for a program of limitations. He proposed that James be banished from England for either five years or for the lifetime of Charles II. He called for an automatic meeting of Parliament within six months of the succession of a Catholic monarch. In order to prevent any Catholic king from establishing arbitrary government, Halifax recommended that Parliament wrest major powers ${ }^{154}$ Jones, Country and Court, p. 212. 
from his hands. A Catholic king would be denied the right to veto bills, the right to fill ecclesiastical positions, and the right to appoint officers of the state or the military. 155

James howled in horror when he heard of Halifax's proposals. He declared:

To say truth what I hear they are a going on with in the House of Lords will be as bad consequence, if not worse to me, and much worse to the monarchy, than the bill that was thrown out.

James correctly stated that the enactment of such limitations would considerably enfeeble the monarchy. But he lacked the imagination necessary to realize that Charles publicly countenanced the limitations only as a ploy to disarm the exclusionists, for Charles was as devoted to the prerogative as James.

The king's public support for Halifax's policy of limitations alarmed William of Orange, who hoped to profit from the attack on James. William instructed his representative van Leeuwen to remonstrate with Charles about the dangerous precedent set by agreeing to accept curtailments upon the powers of any king. This chiding from his nephew infuriated Charles, who quickly explained to William that he would never be foolish enough to actually surrender power to Parliament. Charles reassured William of his devotion to the

${ }^{155}$ Foxcroft, Character, pp. 119, 120, 123, 124. ${ }^{156}$ Turberville, "House of Lords," p. 416. 
royal prerogative and insisted that the policy of limitations would never by enacted. 157

William soon exacerbated Charles's displeasure with him. William persuaded the Dutch States General to present Charles with a memorial asking him to come to terms with Parliament. Sydney forwarded the memorial to London on November 25. Charles regarded the memorial as an impertinent effort by William to advance his own pretensions to the Crown. ${ }^{158}$ The king lambasted his envoy Sidney for encouraging William's impudence and henceforth treated van Leeuwen with scant courtesy.

The Earl of Essex proposed another alternative to the exclusion of James from the succession. He favored the creation of an Association, similar to the one created during the reign of Queen Elizabeth. Its goal would be to secure the acceptance of limitations by the future king and to protect the life of the present king. As a means of ensuring that the successor would accept the policy of limitations once he came to the throne, Essex proposed that several key towns be placed under the jurisdiction of the Association. 159

Charles found the proposal that he surrender his authority

$$
\begin{aligned}
& 157_{\text {Haley, First Earl, }} \text { p. } 605 . \\
& 158_{\text {Kenyon, Sunderland, }} \text { p. } 69 . \\
& { }^{159} \text { Turberville, "House of Lords," p. } 416 .
\end{aligned}
$$


over many of England's most important cities absolutely reprehensible. He confided to Burnet that:

He looked on this as a deposing of himself... he had a clear view into the consequences of such things, and looked on this as worse than the exclusion. . . . The King came to think that he himself was levelled at chiefly though for decency's sake his brother was only named."

After the defeat of the second Exclusion Bill, the Whigs turned their attention to removing the eloquent and implacable Halifax from the king's side. Lady Sunderland expressed the sentiments of the Whigs when she wrote, "Lord Halifax is the King's favourite, and hated more than ever the Lord Treasurer was, and has really deserved it, for he has undone al1."161 The Whig assault on Halifax began just two days after the Exclusion Bill went down to defeat. On November 17 Montagu moved that the House of Commons vote an address against Halifax, accusing him of advising the dissolution of the first Exclusion Parliament in July of 1679. The motion passed 213 to $101 .^{162}$ The House presented this address for Halifax's removal to Charles on November 22. Charles rejected it, informing the House that he considered their reasons for requesting Halifax's removal insufficient, since Halifax had done nothing contrary to the law. 163

160 Burnet, History, p. 259.

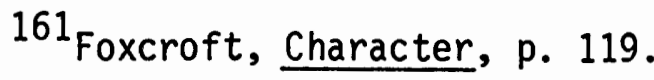

162 Jones, First Whigs, p. 142.

${ }^{163}$ Browning, Reresby, p. 204. 
The Whigs decided to devote the remainder of the session to paving the way for the reintroduction of exclusion. Their effort to persuade the king that the government would be incapable of functioning until he accepted exclusion constituted a key part of this program. To obtain this end, the House of Commons resorted to blackmail. On November 17 Charles had reiterated his request that Commons vote money for the defense of Tangier. For several weeks members pondered how best to turn this foreign crisis to their own advantage. The king repeated his request for aid for Tangier on December 15, warning members that their reluctance to defend an English possession had damaged England's prestige abroad. Members intent upon obtaining exclusion dismissed the plight of the city as unimportant. Colonel Titus declared, "Whoever speaks now of Tangier ought to do it with some apology. To talk of the condition of Tangier now, is like Nero, when Rome was on fire, to fiddle." 164

Finally, on December 21, the House of Commons responded to the king's request for aid for Tangier. The House presented Charles with an address on that date declaring that the members could see no safety for England without the exclusion of James from the succession and the creation of an Association to guarantee that the Protestant successor came to the throne. ${ }^{165}$ If the king ${ }^{164}$ Grey, Debates, Vol. VIII, p. 11. ${ }^{165}$ Haley, First Earl, p. 615. 
accepted these demands, his grateful Commons would vote an ample supply for the defense of Tangier.

The House of Commons had adamantly refused to accept a Protestant Association as a substitute for exclusion, but now the House was determined that an Association be included as an integral part of any Exclusion Bill. Charles correctly viewed this demand for an Association as a declaration of war upon his own prerogatives. For according to the House of Commons' address, this Association would oversee the implementation of safeguards designed to secure a Protestant succession. Key towns, ports and arsenals would fall under the jurisdiction of the Association during Charles II's lifetime; this to insure that when Charles died the Protestants would be well-placed to rebuff any Catholic attempt to place James on the throne. This proposal allowed Parliament the right to fill vacancies in the Militia, the Admiralty, and even in the Privy Council. 166 Supporting James's title to the throne constituted an act of treason, punishable by removal from office and prosecution. 167 Only men who supported the Protestant succession could serve as judges, justices of the peace, sheriffs, Lords Lieutenants, magistrates, army and naval officers, and every other position of responsibility. ${ }^{168}$ The realization of these demands would eradicate

${ }^{166}$ Sitwel1, First Whig, p. 142.

167 Jones, First Whigs, pp. 146-147.

${ }^{168} \mathrm{Haley}$, First Earl, p. 615. 
every vestige of monarchial authority and leave the king, in the words of James, a "doge of Venice." 169 The demands of this address bore out Charles's fears that the exclusion movement was a doubleedged sword, threatening both implicitly and explicitly to curtail the royal prerogative.

The loyal ministers of the Crown, already under fierce attack from the House of Commons, declared that Charles must either give in to the Whigs' demands or dissolve Parliament in order to be rid of this House of Commons. Charles made one last effort to dissuade members from pursuing their struggle for exclusion. On January 4, 1681, Charles sent his reply to the Commons' address. The king declared that he would never consent to an Exclusion Bill and he urged them to adopt other measures for protecting the Protestant religion. He reminded them that the House of Lords had concurred with his opinion of the bill, and said that their stubborn insistence upon enacting exclusion disappointed him. Once again, he asked for aid for Tangier. 170

The members of the House declared that they would "put a brand" upon those ministers who had advised Charles to reject their addresss. Commons prepared to begin impeachment proceedings against the Crown's ministers and several judges. This concerted attack upon his ministers and judges persuaded Charles that he had nothing to gain from the continuation of this Parliament. Accordingly,

169 Haley, First Earl, p. 448 , citing a letter from James to William of Orange, dated May 21, 1678.

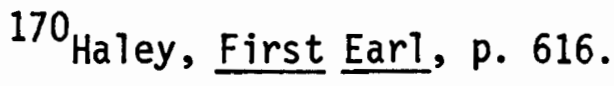


Charles prorogued Parliament on January 10 and dissolved it eight days later, summoning a new one to meet at 0xford on March 21.

This decision to have the new Parliament meet at Oxford, traditionally a royalist town, alarmed the Whigs. They feared that Charles would take advantage of the surroundings to order the arrest of his opponents. Monmouth and fourteen other peers petitioned Charles to permit the Parliament to assemble in London. ${ }^{171}$ The king ignored their petition, preferring for Parliament to assemble outside of the Whig stronghold of London.

The king demonstrated his unwillingness to surrender when he dismissed from his Privy Council all the members who had voted for exclusion, including Shaftesbury, Sunderland, Essex and Temple. 172 This blow fell heaviest on Sunderland, who was ordered to surrender up his seals of office without being reimbursed the $L 6000$ that he paid for the right to be Secretary of State. 173

On January 23 Sidney recorded in his diary a conversation that he had with William of Orange, in which William declared that, "He believes that the King has taken measures with France, and so does everybody."174 William correctly assessed Charles II's actions. The uncompromising attitude of the House of Commons

$$
\begin{aligned}
& 171_{\text {Russe } 11, \text { Life of Russell, }} \\
& 172_{\text {Ibid. }} \\
& 173_{\text {Kenyon, Sunderland, p. } 73 .} \\
& 174_{\text {Sidney, Diary, ․ } 161 .}
\end{aligned}
$$


drove Charles to accept the patronage of Louis XIV rather than the dictates of his House of Commons. Beginning in January, Charles renewed his negotiations with Louis XIV for a subsidy. On March 22, the day after the Oxford Parliament met, the kings struck a bargain. In exchange for his promise not to call Parliament, Charles would receive from France 2, nNO, n00 livres the first year of the agreement and 1,500,000 livres in each of the following years. ${ }^{175}$ This subsidy allowed Charles to exist without being financially dependent upon Parliament, and allowed him to rob the Whigs of their platform for opposition.

The Parliamentary elections of February 1681 witnessed the creation of another Whig majority. As Burnet wrote:

The elections over England for the new Parl iament went generally for the same persons that had served in the former Parliament; and in many places it was given as an instruction to the members to stick to the bill of exclusion.

Burnet described a practice which grew out of the 1681 elections-the presentation of instructions to newly-elected Whig members of the House of Commons. The leading Whigs drew up a set of instructions for new members, calling upon them to accept only exclusion and to reject all other expedients. ${ }^{177}$ These instructions also encouraged the members to pass legislation calling for annual Parliaments.

$$
\begin{aligned}
& { }^{175} \text { Grose, "Louis XIV," pp. 200-201. } \\
& 176_{\text {Burnet, History, pp. 275-276. }} \\
& 177 \text { Jones, Restored Monarchy, pp. 57-58. }
\end{aligned}
$$


This usurpation of the royal prerogative of dissolution would allow the Whig-dominated House of Commons to be recaicitrant without the danger of being sent packing.

Charles opened Parliament on March 21 with a speech which firmly stated his opposition to exclusion and to any Parliamentary encroachments upon the royal prerogative. The king assured the members that, "I, who will never use arbitrary government myself, am resolved not to suffer it in others." 178 He assured them that:

.. . neither your liberties nor properties can subsist long, when the just rights and prerogatives of the Crown are invaded, or the hongys of the government brought low, and into disreputation.

And he repeated his willingness to accept a policy of limitations rather than exclusion. "I shall be ready to hearken to any such expedient by which the religion might be preserved, and the monarchy not destroyed." 180

Once again, Charles II espoused support for a policy of limitations which he had no intention of allowing to be implemented. The king could safely offer such limitations, for he knew that his whig opponents would reject them. This allowed the king to appear conciliatory while forcing the Whigs to bear the responsibility for the failure of the two parties to effect a compromise. Charles

$$
\begin{aligned}
& 178_{\text {Russe 11, Life of Russell, p. } 258 .} \\
& 179_{\text {Ibid, p. } 259 .} \\
& 180_{\text {Ibid., p. } 261 .}
\end{aligned}
$$


could then place the blame for the inevitable dissolution of Parliament on the shoulders of the Whigs, who had refused to meet him hal fway.

In accordance with this scheme, Sir Thomas Littleton, acting on the king's instructions, proposed a new plan to limit the powers of a Catholic successor. This plan allowed James to retain the title of king while William and Mary exercised all the powers of the monarch, acting as regents for James, who would be in permanent exile. ${ }^{181}$ The Whigs lost no time in pointing out the weaknesses of such a regency. Mary might refuse to cooperate, and even if she did, the regency plan might not be legally binding upon James. Winnington called the regency a nonsensical contradiction, pointing out that once James held the title of king, the loyal judges would rule that by possessing the title, he had the right to exercise the powers of the office. 182

Exclusion was the aim and purpose of the Whig House of Commons; no alternatives would gain their approval. On March 26, Sir Robert Clayton moved that an Exclusion Bill be brought in. After a long debate, in which the Tory members attempted to forestall the attack upon James, a resolution for a new Exclusion Bill passed the House. The bill received its first reading on March 28, shortly before Charles appeared and suddenly dissolved Parliament.

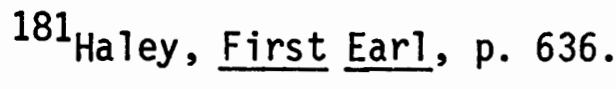

$$
\begin{aligned}
& { }^{182} \text { Grey, Debates, Vol. VIII, pp. 325-326. }
\end{aligned}
$$


By repudiating the king's offer to limit the powers of a Catholic successor, the Whigs had accomplished what Charles had intended them to when he called the Oxford Parliament. Their intransigence allowed him to blame the whigs for the failure to reach a compromise. The astute Halifax realized this when he wrote to Burnet:

If you are rightiy informed that the expedients were never intended by one side, I am sure they were unskillfully refused by the other; for next to gaining the point quiffo the best is to put those wee differ with in the wrong."

Popular excitement over the Plot had dwindled to the point where Charles could dissolve Parliament, without being accused of doing so to protect the Catholics. The French subsidy would allow him to survive without Parliament's financial support. Charles relied upon his prerogative power of dissolution to put an end to the exclusion movement. Determined never to surrender his prerogatives or his brother's rights, the king did not call another Parliament.

${ }^{183}$ Dorothy Lane Poole, "Some Unpublished Letters of George Savile, Lord Halifax to Gilbert Burnet," English Historical Review, Vol. 26 (1911), p. 541. 


\section{CHAPTER VII}

\section{CONCLUSION}

Charles II dismissed his last Parliament in the spring of 1681 convinced that the victory was his. As long as he avoided expensive foreign entanglements, the subsidy from Louis XIV would allow him to scrape by financially. He realized that, in resisting exclusion, he had protected both James's right to the Crown and the royal prerogative. The political and constitutional questions raised during the course of the Exclusion Crisis were ones which reverberated throughout the seventeenth century. As a result of the civil war, the Crown had lost several prerogative powers, but this loss of power did not permanently tip the scale in favor of Parliament. Charles II's reign inevitably witnessed attempts to better define the balance of power between the king and Parliament.

By the late 1670s the Restoration settlement was clearly inadequate. The king's attempt to rule by relying upon the royal prerogative in the early 1670s, and Danby's attempt to free the king from financial dependence upon Parliament in the middle and late 1670 s, raised the spectre of royal absolutism. The sons and grandsons of the men who had fought Charles I in the 1640 s were determined not to surrender the powers and privileges that they had won in contest with that king. The outbreak of the Popish Plot and the ensuing anti-Catholic hysteria offered an opportunity 
to settle unresolved questions about the nature of the monarchy and the extent of the royal prerogative. The campaign to exclude the Duke of York from the succession constituted an attempt to redefine the limits of royal authority, as well as an effort to protect the Church of England.

Most Englishmen associated Catholicism with absolutism. Shaftesbury relied upon this sentiment when he worked to channel the nation's anger over the discoveries of the Popish Plot into political activity. James's Catholicism offered a neat issue upon which to base his campaign to limit the scope and extent of the royal prerogative. As this thesis has demonstrated, religion was not the only issue during the Exclusion Crisis. On the pretext of protecting Protestantism, the members of the Exclusion Parliaments attempted to encroach upon almost every prerogative remaining to the king.

The Cavalier Parliament, in the autumn of 1678, challenged the king's control over the armed forces. This session witnessed the inception of a new political principle when the House of Commons began impeachment proceedings against the Earl of Danby. The principle that Crown ministers bore responsibility for unpopular, as well as illegal, acts boded ill for the king's ability to exact obedience from his ministers.

The members of the First Exclusion Parliament continued their attempt to impeach Danby. In the course of this effort, the House of Commons challenged the king's authority to issue pardons. This conflict produced an attempted reappraisal of the Commons' right 
to impeach ministers and the king's ability to circumvent this by pardoning his ministers. Both sides insisted upon their rights; this important constitutional question remained unsettled. This House of Commons also endeavored to usurp the fundamental royal prerogative of deciding when a Parliament would be dissolved. The loss of this power would, of course, considerably limit the king's ability to resist the will of his Parliament.

In the autumn of 1680 , the members of the Second Exclusion Parliament again denied the king's right to issue pardons. They attacked his ministers. This session witnessed an ominous development-the linking of an Exclusion Bill with a proposal for a Protestant Association. In their determinatin to obtain exclusion, the members of Commons hoped to render the king incapable of opposing them. Members sought to arrogate to Parliament the right to appoint most office-holders. They demanded that jurisdiction over several key cities, ports, and arsenals fall into the hands of the Association. Those men who denied Parliament's right to alter the succession in defiance of the king's will, and who insisted upon supporting James's right to the throne, would be prosecuted as traitors.

Al though it lasted only a week, the Third Exclusion Parliament in the spring of 1681 showed every sign of continuing the campaign to limit the prerogative. The instructions which whig leaders presented to the members of the new House of Commons directed the members to accept only exclusion and to propose a bill calling for annual Parliaments. 
The activities of the Exclusion Parliaments verify the contention of this thesis that political and constitutional issues were paramount during the Exclusion Crisis. In the course of the struggle, Parliament challenged the prerogatives of the king. Exclusion, itself, would damage the prerogative by creating a Parliamentary title to the throne.

The men close to the king realized that Charles considered the exclusion campaign to be directed as much against his prerogatives as against the expectations of James. Secretary of State Jenkins wrote to Sidney explaining the reasons for the dissolution of the Third Exclusion Parliament:

- . nothing but the exclusion of the duke would serve their turn; and t'was plain, nay, which is more, t'was confessed, an association, the militia, the fleet would have been demanded as securities requisite to make good the exclusion. 184

Reresby reflected much the same sentiment when he wrote in his memoirs :

Some of the party had blab'd it in the Hous that this was not only the material bil that they intended should pass this session to secure the people of England from falling under popery and absolute government; that it was nescessary that both the military and civil power should be put into other hands, and that the present officers of both ought to be examined and changed; insoemuch as the king was tould that if he quitted the Duke, it was but to be a step both to quitt all his friends and servants afterwards, and to fall entirely into the hands of people that had reason to thinke were not soe wel affected to his person and government."185

184

Sidney, Diary, pp. 185-186.

185 Browning, Reresby, pp. 223-224. 
Throughout the crisis Charles II kept a cool head, resisting the temptation to use strong-arm tactics to disable his opponents. Charles II possessed an invaluable weapon, the right to dissolve Parliament at will. As long as he could exercise this right, he could cripple any Exclusion Bill. The king's defeat of the exclusion movement in the spring of 1681 rested upon his right to exercise this prerogative. The Exclusion Crisis left unsettled the question of the balance of power between the king and Parliament. 


\section{SELECTED BIBLIOGRAPHY}

A. Primary Sources:

1) Browning, Andrew, ed. Memoirs of Sir John Reresby, Jackson, Son \& Company, Glascow, 1936.

2) Bryant, Sir Arthur, ed. The Letters, Speeches and Declarations of Charles II, Cassel1, London, 1968 .

3) Burnet, Bishop History of His Own Time, with notes by the Earls of Dartmouth and Hardwicke, Speaker Onslow, and Dean Swift, 6 vols., University Press, Oxford, 1833.

4) Grey, Anchite11, Esq., Collector Debates of the House of Commons, from the year 1667 to the year $1694, \frac{10}{10}$ vols., T. Becket and P.A. De Hondt, The Strand, 1769 .

5) Laslett, Peter, ed. Patriarcha and Other Political Works of Sir Robert Filmer, Basil Blackwel1, Oxford, 1949.

6) Luttrell, Narcissus A Brief Historical Relation of State Affairs from September $\frac{1678}{1657}$ to April $\frac{1714}{\text {, Vo1. I, Oxford University }}$ Press, Oxford, 1857 .

7) Sidney, Henry Diary of the Times of Charles II, Blencowe, R.W., ed., Henry Colburn Publishers, London, 1843.

8) Thompson, Edward Maunde Correspondence of the Family of Hatton, Being Chiefly Letters Addressed To Christopher First Viscount Hatton AD 1601-1709, Vo7. I, Camden Society, 1878. 
B. Secondary Sources:

1) Ashley, Maurice Charles II: The Man And The Statesman, Praeger Publishers, New York and Washington, 1971.

2) Baxter, Stephen B. William III And The Defense of European Liberty, 1650-1702, Harcourt, Brace and World, Inc., New York, 1966.

3) Burghclere, Lady The Life of James, First Duke of Ormonde, 1610-1688, John Murray, London, 1912.

4) Feiling, Keith A History of the Tory Party 1640-1714, Clarendon Press, 0xford, 1924.

5) Foxcroft, H.C. A Character of the Trimmer, University Press, Cambridge, 1946.

6) Fraser, Antonia Royal Charles, Charles II and the Restoration, Al fred A. Knopf, New York, 1979.

7) Gilmour, Margaret The Great Lady: A Biography of Barbara Villers, Mistress of Charles II , Alfred A. Knopf, New York, 1941.

8) Haley, K.H.D. The First Earl of Shaftesbury, Clarendon Press, Oxford, $1 \overline{968}$.

9) Harvey, J. and L. Bather The British Constitution, St. Martins Press, New York, 1968.

10) Jones, J.R. Country and Court, England, 1658-1714, University Press, Cambridge, 1978.

11) Jones, J.R. The First Whigs: The Politics of the Exclusion Crisis 1678-1683, Oxford University Press, New York and Toronto, 1961 .

12) Jones, J.R., ed. The Restored Monarchy 1660-1688, MacMillan Press Ltd., London, 1979.

13) Kenyon, J.P. The Stuart Constitution 1603-1688, Documents and Commentary, Cambridge, 1966.

14) Kenyon, J.P. Robert Spencer, Earl of Sunderland 1641-1702, Longmans, Green and Company, London, New York and Toronto, 1958. 
15) Lacey, Douglas R. Dissent and Parliamentary Politics in England 1661-1689, Rutgers University Press, New Brunswick, 1969.

16) Lee, Maurice Jr. The Cabal, University of Ill ino is Press, Urbana, 1965.

17) Lever, Sir Tresham Godolphin, His Life and Times, John Murray, London, 1952.

18) Maitland, F.W. The Constitutional History of England, University Press, Cambridge, 1948.

19) Miller, John Popery and Politics in England 1660-1688, University Press, Cambridge, 1973.

20) Price, Cecil Cold Caleb: The Scandalous Life of Ford Grey, First Earl of Tankerville 1655-1701, Andrew MeTrose, London, 1956.

21) Roberts, Clayton The Growth of Responsible Government in Stuart England, University Press, Cambridge, 1966.

22) Ronalds, Francis $S$. Attempted Whig Revolution of 1678-81, Rowman and Littlefield and the Boydell Press, $\frac{\text { At }}{1974}$ (1937), Totowa, New Jersey.

23) Russell, Lord John The Life of William Lord Russell, Vol. I, Longman, Hurst, Rees, Orme and Brown, London, 1820.

24) Sitwell, Sir George The First Whig, printed by the author at his private press, Scarborough, 1894.

25) Tanner, J.R. English Constitutional Conflicts of the Seventeenth Century, 1603-1689, University Press, Cambridge, 1962.

26) Taswell-Langmead, Thomas Pitt Engl ish Constitutional History, Houghton Miffl in Company, 1947.

27) Turner, F.C. James II, Eyre and Spottiswoode, London, 1950.

28) Western, J.R. Monarchy and Revolution, The English State in the 1680s, Bl andford Press, London, 1972 .

29) Woodbridge, Homer E. Sir Will iam Temple, The Man and His Work, Modern Language Association of America, New York, 1940; reprinted by Kraus Reprint Corporation, New York, 1966. 
C. Articles:

1) Abbott, Wilbur C. "The Origin of English Political Parties," American Historical Review, XXIV(4), July 1919, 578-602.

2) Edie, Carolyn Andervont "Succession and Monarchy: The Controversy of 1679-1681," American Historical Review, 1966.

3) Feiling, Keith and F.R.D. Needham "The Journals of Edmund Warcup, 1676-84," English Historical Review, 40, April 1925, 235-260.

4) Fryer, C.E. "The Royal Veto Under Charles II," English Historical Review, 32, January 1917, 103-111.

5) Grose, Clyde "French Ambassador's Reports on Financial Relations with Members of Parliament, 1677-81," Engl ish Historical Review, CLXXVI, October 1929, 625-628.

6) Grose, Clyde L. "Louis XIV's Financial Relations With Charles II and the English Parliament," Journal of Modern History, I(2), June 1929, 177-204.

7) Lipson, E. "Elections to the Exclusion Parliatments, 1679-81," English Historical Review, 28, 1913, 59-85.

8) Poole, Dorothy Lane "Some Unpublished Letters of George Savile, Lord Hal ifax, to Gilbert Burnet," English Historical Review, XXVI, 1911, 535-542.

9) Temperley, H.W.V. "Inner and Outer Cabinet and Privy Council, 1679-1783," English Historical Review, 27, October 1912, 682-699.

10) Turberville, A.S. "The House of Lords Under Charles II ," English Historical Review, XLIV and XLV, July 1929 and January 1930, 400-417 and 58-77.

11) Turner, Raymond "Charles II's Part in Governing England," American Historical Review, XXXIV, October 1928.

12) Turner, Edward Raymond "The Privy Council of 1679," English Historical Review, 30, April 1915, 251-270. 